\title{
Z FILOLOGII ŚLEDCZEJ. PRACA AGENTURALNA STALINOWSKICH SŁUŻB SPECJALNYCH ZA GRANICĄ NA PRZYKŁADZIE SPRAWY O ZABÓJSTWO IGNACEGO REISSA
}

\author{
GRZEGORZ OJCEWICZ \\ Prof. em. Wyższej Szkoły Policji w Szczytnie, Polska \\ e-mail: gojcew@poczta.onet.pl \\ (nadesłano 21.06.2017; zaakceptowano 5.07.2017)
}

\section{Abstract \\ From Investigative Philology. Agency activity of Stalin's intelligence service as illustrated by the Ignace Reiss' assassination case}

In order to illustrate the agency activity of Stalin's intelligence service abroad in the 1940s I have selected a notorious case of the assassination of a prominent Soviet spy, Ignace Reiss, which took place on 4 September 1937 near Lausanne. I have set three main research objectives: 1 . to verify the current state of knowledge on the assassination of Ignace Reiss; 2. to establish the possible involvement of Sergei Efron in the assassination; 3. to evaluate to what extent the fate of Sergei Efron in relation to the assassination of Ignace Reiss influenced the lives of his own family members (Marina Tsvetaeva, Ariadna Efron and Georgy Efron) and his immediate agency circle. As for today, there are strong grounds to state that Sergei Efron was not directly involved in Reiss' killing - presumably, he did not shoot him. Following the unmasking of the espionage network in Paris led by Efron, his family and Efron himself were forced to abandon France in a hurry. Soon after that Efron and his relatives experienced Stalin's repression of the Great Terror. Efron was executed by the NKVD, Marina Tsvetayeva committed suicide, Ariadna Efron was placed in prison for many years and Georgy Efron, 19 years old at the time died in Belarus in August 1944, merely two months after having fought at the front in the Second World War. 


\section{Key words}

The first wave of Russian emigration, Soviet agency, Ignace Reiss, Lausanne assassination, the death of a Soviet spy.

\section{Резюме}

\section{Из следственной филологии. Агентурная работа сталинских спецслужб за границей на примере дела об убийстве Игнатия Рейсса}

Чтобы проиллюстрировать агентурную работу сталинских спецслужб за границей в 40-е гг. XX в., я выбрал громкое дело об убийстве выдающегося советского шпиона, Игнатия Рейсса, которое совершилось 4 сентября 1937 года под Лозанной. Перед собой я поставил три главные исследовательские цели: 1. проверить новейший уровень знаний об убийстве Игнатия Рейсса; 2. определить потенциальную роль Сергея Эфрона в данном убийстве; 3. оценить, как судьба самого Сергея Эфрона в связи с коварной смертью Игнатия Рейсса повлияла на жизнь его собственной семьи (Марины Цветаевой, Ариадны Эфрон и Георгия Эфрона) и ближайшего агентурнуго окружения. На сегодняшний день мы имеем больше аргументов, свидетельствующих о том, что Сергей Эфрон не принимал непосредственного участия в убийстве Рейсса, т.е. он в него не стрелял. Вследствие деконспирации шпионской сети в Париже, которой он руководил, сам Эфрон и его семья были принуждены покинуть Францию. Эфрон и члены его семьи вскоре были подвержены сталинским репрессиям в рамках великого террора. Эфрон был расстрелян НКВД, Марина Цветаева наложила на себя руки, Ариадна Эфрон попала на долгие годы в лагерь, а 19-летний Георгий Эфрон погиб на Беларуси в августе 1944 года, уже через два месяца с момента пребывания на фронте II мировой войны.

\section{Ключевые слова}

Русская эмиграция первой волны, советская агентура, Игнатий Рейсс, убийство под Лозанной, смерть советского шпиона.

\section{Wstęp}

Szpiegostwo jest stare jak świat. Można nawet powiedzieć, uwzględniając historię Adama i Ewy oraz Węża, że ma ono biblijne źródła. Działalność szpiegów przechodziła przez tysiąclecia określoną ewolucję, by z działań na ogół amatorskich i doraźnych przemienić się $\mathrm{w}$ permanentną aktywność wywiadowczą $\mathrm{w}$ ramach rozbudowanych oficjalnych instytucji państwowych, penetrujących własny kraj i obce państwa głównie w celach politycznych oraz militarnych. Dlatego nie może dziwić fakt, że wraz z pierwszą falą emigrantów rosyjskich na obczyźnie znaleźli się ludzie, którzy świado- 
mie podejmowali płatną współpracę z organami NKWD i bezwzględnie wykonywali wszelkie polecenia, jakie otrzymywali z Moskwy, łącznie z organizacją zamachów na życie wytypowanych przez Iosifa Stalina (1878-1953) osób, dokonywania perfidnych zabójstw, likwidowania członków rodzin agentów. Nagrodą za pomyślnie wykonane zadanie były najczęściej środki finansowe i wysokie odznaczenia państwowe, co w warunkach emigracyjnego niedostatku czy wręcz biedy okazywało się dostatecznie waż$n e^{1}$. Nie może również dziwić fakt, że „W okresie stalinowskim radziecki wywiad służył partii, a ściślej, jej Komitetowi Centralnemu, a jeszcze ściślej - Stalinowi, którego wolę, którego rozkazy, a niekiedy i kaprysy wypełniał bezwarunkowo. Jednym z takich kaprysów była patologiczna nienawiść do Lwa Trockiego i takież samo pragnienie jego zlikwidowania oraz jego zwolenników. Do wykonania tego zadania rzucono najlepsze siły wywiadu i, jak się to mówi, z wielkim zaangażowaniem, godnym lepszej sprawy, wykonywały one wskazane zadanie"2.

Środowisko rosyjskich emigrantów pierwszej fali nie było jednorodne. Znajdowali się w nim zwolennicy dawnej monarchii, nastawieni przeciwko ZSRR, jak też osoby o prosowieckiej i prostalinowskiej orientacji. Idee rewanżu za krach caratu i marzenia o zbrojnej interwencji obcych mocarstw na Kraj Rad były równoważone przez pragnienia powrotu do ojczyzny. To oczywiste, że w myśl zasady „dziel i panuj” Kreml starał się wykorzystać do swoich celów politycznych i propagandowych to swoiste rozchwianie postaw, nastrojów i oczekiwań wśród byłych obywateli Imperium Rosyjskiego. Dlatego Stalin angażował aparat szpiegowski za granicą, by osłabiać jedność wśród emigrantów rosyjskich i zapewnić sobie stały dopływ informacji o tym, co się dzieje w innych krajach. Dlatego też agenci NKWD przedostawali się do organizacji emigracyjnych, związków, towarzystw, lóż masońskich, penetrowali wszystkie środowiska, zajmowali się porwaniami liderów tzw. białego ruchu na obczyźnie, wykonywali pozasądowe wyroki śmierci na osobach, które jawnie występowały przeciwko radzieckiemu systemowi totalitarnemu³. W styczniu 1930 roku tzw. grupa Jaszy, czyli agenta OGPU ${ }^{4}$ Jakowa Sieriebranskiego (1891-1956) porwała w Paryżu generała Aleksandra Kutiełowa (1882 - po 26 I 1930), a przy pomocy agenta NKWD ${ }^{5}$, białego generała Nikołaja Skoblina (1893-1939) , również w stolicy Francji, dokonano 22 września 1937

\footnotetext{
1 Na przykład mieszkająca w Paryżu matka Władimira Prawdina, domniemanego zabójcy Ignacego Reissa, otrzymała z Moskwy już po zamordowaniu Reissa czek na dziesięć tysięcy franków, który miała jej przekazać Wiera Guczkowa-Traill. Zob. np.: Великие операции спецслужб. Между первой и второй мировыми войнами. Конфеты из Лозанны. [Online:] <http://greatoperation.narod. ru/3/konfloz.htm> (dostęp: 6.06.2017) oraz <https://www.e-reading.club/chapter.php/39551/54/ Mlechin_-_Sluzhba_vneshneii_razvedki.html> (dostęp: 11.06.2017).

2 Великие операции спецслужб...

3 Zob. np.: Тени замка Арсин. [Online:] <http://www.travel-journal.ru/phenomenons/2/576/> (dostęp: 6.06.2017).

4 OGPU / ОГПУ (= Объединённое государственное политическое управление / Zjednoczony Państwowy Zarząd Polityczny) - organ działający od 2 XI 1923 do 10 VII 1934.

5 NKWD / НКВД (= Народный комиссариат внутренних дел / Ludowy Komisariat Spraw Wewnętrznych - organ działający od kwietnia 1934 do marca 1946.

6 Sam Skoblin zginął najprawdopodobniej w zamachu na jego życie, zorganizowanym przez inną komórkę operacyjną NKWD.
} 
roku porwania innego generała, Jewgienija Millera (1867-1939), będącego przywódcą wojskowej antykomunistycznej emigracji rosyjskiej na Zachodzie i stojącego na czele „Związku Ogólnowojskowego”7. Z pewnością także zabójstwo Lwa Trockiego (18791940), człowieka, który miał odwagę zachowania niezależnych poglądów na rewolucję październikową i dalsze, poleninowskie, losy Rosji, mieści się w ramach tych samych likwidatorskich planów Stalina.

Z inicjatywy Moskwy w emigracyjnym Paryżu działała na przykład organizacja pod nazwą "Związek Powrotu do Ojczyzny", którą kierował nie kto inny, jak mąż Mariny Cwietajewej (1892-1941) - Siergiej Efron (1893-1941), były biały oficer, człowiek o wielu talentach i wielu twarzach. Organizacja ta, utrzymywana przez Kreml, była jedynie przykrywką dla pracy agenturalnej: w rzeczy samej Efron (zwłaszcza on) i jego współpracownicy zajmowali się werbowaniem nowych agentów do kolaboracji ze stalinowskim reżimem. Niewątpliwym sukcesem Efrona było pozyskanie do pracy wywiadowczej pisarza i historyka Nikołaja Klepinina (1899-1941) ${ }^{9}$ i jego żony, Antoniny (Niny) Klepininy (z d. Nasonow; 1894-1941) ${ }^{10}$.

\section{Przed 17 lipca 1937}

Nazwisko Ignacego Reissa pojawiło się przede mną w trakcie lektury artykułu emigrantki rosyjskiej Kseni Kriwoszeiny (1945), znawczyni życia i twórczości św. Matki Marii (Skobcowej; 1891-1945), poświęconego palindromowym związkom między tą prawosławną paryską zakonnicą a Mariną Cwietajewą ${ }^{11}$. Kriwoszeina pisze:

Kusiciel [Aleksiej - G. O.] Tołstoj był ściśle związany z Efronem, który w swoim bolesnym miotaniu się ostatecznie wstąpił na wydział filozoficzny Uniwersytetu Praskiego. Kimże Efron w swoim życiu był! Publicystą, literatem, oficerem Białej Armii, „markowcem” - żołnierzem Siergieja Markowa, „pierwszomarszowcem” - uczestnikiem Pierwszej Kubańskiej Kampanii młodej Armii Ochotników zimą-wiosną 1918 roku, eurazjatą, agentem NKWD i, nie zapominajmy o doprawdy ważnym etapie - aktorem teatru i cyrku. Niewykluczone, że teatralna gra sceniczna całkiem logicznie wiązała się z jego ostatnią rolą $\mathbf{w}$ przygotowaniu zamachu na Ignacego Reissa. Historia ujawnia, że już w czeskich latach udało się mu zwerbować swoich przyjaciół, małżeństwo Klepininów oraz

\footnotetext{
7 Ros. „Общевоинский союз”. Bogatą listę „wyczynów” tego typu w wykonaniu OGPU i NKWD można znaleźć w książce Piotra Krasnowa. Zob.: П. Краснов. Ложь. Париж: Издательство В. П. Сияльского, 1939; <https://books.google.pl/> (dostęp: 11.06.2017).

8 Ros. „Союз возвращения на родину”.

9 Nikołaj Klepinin był starszym bratem ojca Dmitrija Klepinina (1904-1944), prawosławnego kapłana i najbliższego współpracownika św. Matki Marii (Skobcowej, 1891-1945), działającego w paryskiej cerkwi przy ulicy Lourmel 77.

10 Akcent polski: Antonina (Nina) Klepinina (Nasonowa) urodziła się w Warszawie. Była córką Nikołaja i Jekatieriny Nasonowów. Z pierwszego związku małżeńskiego z Wilhelmem Sezemanem miała dwóch synów: Aleksieja i Dmitrija. Z drugiego - z Nikołajem Klepininem - córkę Sofię. Więcej: [Online:] <https://www.geni.com/people/Антонина-Клепинина/6000000006373302671> (dostęp: 6.06.2017).

11 К. Кривошеина. Неэвклидов палиндром имен и судеб, небесных и не очень. [Online:] <http:// mere-marie.com/life/neevklidov-palindrom-imen-i-sudeb/> (dostęp: 22.10.2016); „Новый журнал” 2016, nr 10. [Online:] <http://newreviewinc.com/kseniya_krivosheina/> (dostęp: 18.10.2016).
} 
Konstantina Rodziewicza (który został kochankiem Mariny Cwietajewej, i, najpewniej, ojcem jej syna, Mura - Gieorgija). Związki Efrona z Tołstojem były tajne i stałe ${ }^{12}$.

Stąd, ze zdania, że „teatralna gra sceniczna całkiem logicznie wiązała się z jego ostatnią rolą w przygotowaniu zamachu na Ignacego Reissa”, popłynął zasadniczy impuls śledczy, za którym pojawiły się trzy główne cele badawcze: 1. sprawdzić, jaki jest najnowszy stan wiedzy o okolicznościach zabójstwa Ignacego Reissa; 2. określić, jaka jest ewentualnie w tym zabójstwie rola Siergieja Efrona - czy tylko organizatora lub współorganizatora, a może jednak także bezpośredniego (współ)wykonawcy wyroku; 3. ocenić, jak losy samego Siergieja Efrona w związku ze skrytobójczą śmiercią Ignacego Reissa wpłynęły na życie jego własnej rodziny (Mariny Cwietajewej, Ariadny Efron i Gieorgija Efrona) oraz najbliższego agenturalnego otoczenia.

Sprawa zabójstwa Ignacego Reissa jest złożona i wielowątkowa, a do tego bardzo trudna, ponieważ nie ma wolnego dostępu ani do archiwów dawnego KGB, ani tajnych archiwów w Szwajcarii. Wydaje się, że do zrozumienia pewnych istotnych faktów i wydarzeń związanych bezpośrednio z zabójstwem wybitnego agenta służb specjalnych, potrzebna jest na początek uporządkowana wiedza, którą można czerpać przede wszystkim z biografii radzieckiego szpiega ${ }^{13}$.

Ignacy Natan Porecki (alias Natan Porecki, Ignacy Reiss s. Stanisława, Ignatz Reiss, Ignace Poretsky, Hans Eberhardt, Steff Brandt, Walter Scott, Ludwig, Ludwik, Reimond; Игнатий Рейсс/Рейс/Райс, Натан Порецкий, Людвиг, Людвик, Раймонд) urodził się w noworoczną niedzielę, 1 stycznia 1889 roku, w galicyjskich Podwołoczyskach nad Zbruczem w zaborze austrowęgierskim, w zamożnej żydowskiej rodzinie kupieckiej jako Nathan Porecki, syn Marka. Po ukończeniu szkoły we Lwowie udał się do Wiednia, gdzie studiował i ukończył prawo na tamtejszym uniwersytecie. Wielu przyjaciół z lat jego młodości i pobytu we Lwowie stało się w przyszłości sowieckimi wywiadowcami. W 1919 roku związał się z polskimi komunistami, zostając członkiem Komunistycznej Partii Robotniczej Polski.

W latach I wojny światowej Porecki odwiedził Lipsk, gdzie spotykał się z niemieckimi socjalistami. W 1918 roku powrócił do rodzinnego miasteczka i podjął się pracy na kolei. Starszy brat Poreckiego, z którym razem się uczył we Lwowie, zginął w 1920 roku podczas wojny polsko-bolszewickiej. W tym samym roku Porecki przybył do Moskwy i wstąpił do partii bolszewików. Wkrótce został współpracownikiem Wszechrosyjskiej Komisji Nadzwyczajnej, znanej bardziej jako CzeKa, zajmującej się przede wszystkim walką z kontrrewolucją i sabotażem ${ }^{14}$. Tutaj pozostawał wierny tej represyjnej insty-

12 Tu i dalej, jeśli nie zaznaczono inaczej, wszystkie cytaty podaję we własnym tłumaczeniu. Także wyróżnienia pochodzą ode mnie.

13 Najpełniejszą na chwilę obecną wiedzę o życiu i działalności Ignacego Reissa zawiera, jak sądzę, książka napisana przez jego żonę, Jelizawietę Porecką, upamiętniająca nie tylko samego Reissa, lecz także jego przyjaciół. W dziele Poreckiej znajdują się następujące rozdziały odzwierciedlające etapy agenturalnej aktywności Natana Poreckiego: List, Polska Partia, Lwów, Berlin/Wiedeń, Praga/Amsterdam, Moskwa, Richard Sorge, Europa, Moskwa, Szwajcaria. Zob. np.: E. K. Poretsky. Our Own People: A Memoir of "Ignace Reiss" and His Friends. London: Oxford University Press, 1969.

14 O tym, jak działa ta represyjna instytucja, napisał na przykład były agent stalinowskich służb specjalnych Gieorgij Agabiekow. Zob.: Г. Агабеков. Г.П.У. Записки чекиста (G.P.U. Notatki czekisty, 
tucji, która zmieniała kolejno szyldy z GPU ${ }^{15}$, na OGPU i NKWD oraz wywiadowi na rzecz Armii Czerwonej. W Moskwie poznał i ożenił się ze studentką medycyny, Jelizawietą Karłowną, ps. konspiracyjny „Elza”, tak samo zauroczoną ideami Lenina, jak jej mąż, tak samo szczerze oddaną hasłom rewolucji październikowej i marzeniom o internacjonalizmie. Młody Porecki musiał być naprawdę dobrym agentem, skoro sam Lenin nazwał go „profesjonalnym rewolucjonistą"16.

W latach 1920-1922 Porecki pracował we Lwowie, zajmując się kolportażem nielegalnej literatury. W związku ze swoją działalnością konspiracyjną został aresztowany w 1922 roku i skazany na 5 lat więzienia. Podczas konwojowania udało się mu zbiec i przez Kraków przedostać się do Niemiec. W kolejnych latach, 1922-1927, Reiss pracował głównie w Europie Zachodniej: Berlinie, Wiedniu, Pradze i Amsterdamie. Kontaktował się wtedy $\mathrm{z}$ wieloma radzieckimi wywiadowcami działającymi nielegalnie, w tym m.in. z Jakowem Blumkinem (1898-1929), Wasilijem Zarubinem (1894-1972), Sándorem Radó (1899-1981) i Janem Berzinem (1889-1938). W 1927 roku otrzymał zadanie utworzenia siatki szpiegowskiej w Wielkiej Brytanii, co się mu najprawdopodobniej udało, skoro w 1928 roku za osiągnięcia wywiadowcze został odznaczony Orderem Czerwonego Sztandaru. W okresie 1929-1932 Reiss ponownie pracował w Moskwie, oficjalnie podejmując działania w polskiej sekcji Międzynarodówki Komunistycznej. Do Zagranicznego Wydziału Wywiadu Politycznego Głównego Zarządu Bezpieczeństwa Państwowego (INO NKWD) ${ }^{17}$ trafił w 1931 roku. Następnie od 1933 roku aż do feralnego lipca 1937 przebywał w Paryżu, będąc rezydentem INO NKWD.

W 1937 roku Jelizawieta Porecka po raz ostatni przyjechała do Moskwy. Tam spotkała się - również po raz ostatni - z zaufanymi towarzyszami Reissa. Ci przekazali przez nią Ludwigowi, który przebywał wówczas w Szwajcarii, ostrzeżenie, by nie wracał do ZSRR i by unikał kontaktów ze swoimi byłymi agentami. Towarzysze Reissa mieli wtedy złożyć swego rodzaju przysięgę: „Ten spośród nas, który przeżyje, kiedyś o nas napisze"18. Później większość z nich, jak dowiodła historia, została zlikwidowana w ramach stalinowskiego terroru. Tylko cudem uniknąwszy zamachu na swoje życie, Jelizawieta Porecka wywiązała się ze złożonej obietnicy i wykonała zadanie, pisząc wspomnienia ${ }^{19}$.

Prawdziwie zaangażowany ideowo Reiss-agent był prawnikiem, człowiekiem kulturalnym, o nienagannych manierach, towarzyskim, łatwo nawiązującym kontakty

Berlin 1930) i Ч.K. за работой (Cz. K. w czasie pracy, Berlin 1931). Książki te przetłumaczono na kilka języków obcych.

15 GPU / ГПУ (= Государственное политическое управление / Państwowy Zarząd Polityczny) organ działający od 6 II 1922 do 2 XI 1923.

16 Л. Клот. Игнатий Рейсс: загадочная смерть советского шпиона под Лозанной | Ignace Reiss, mort d'un espion soviétique à Lausanne. [Online:] <http://nashagazeta.ch/news/14121> (dostęp: 20.05.2017).

17 Ros. „Иностранный отдел политической разведки Главного управления государственной безопасности".

18 Военная титература. Мемуары. [Online:] <http://militera.lib.ru/memo/russian/poretskya_ ek/01.html> (dostęp: 5.06.2017).

19 E. K. Poretsky. Our Own People... 
z nieznajomymi. To cechy wielce pożądane w pracy szpiega i werbownika, który działał głównie w kręgach osób wykształconych - profesorów i dziennikarzy. Miał jednak na sumieniu równie brudne sprawy, jakich sam padł ofiarą, gdy z przekonaniem i ofiarnością brał bezpośredni lub pośredni udział w likwidacji osób wytypowanych przez Kreml. W artykule Wielkie operacje służb specjalnych. Między pierwsza a druga wojna światowa. Cukierki z Lozanny (Великие операции спецслужб. Между первой и второй мировыми войнами. Конфеты из Лозанны $)^{20}$ znajduję katalog przewinień Reissa-agenta. Nie wiadomo, czy jest to pełny spis jego likwidatorskich dokonań, ale nawet to, co zostało ujawnione, już pozwala na wyrobienie sobie negatywnego zdania o ich bohaterze. Tak więc, we wspomnianym tekście mówi się o następujących sprawach z udziałem Reissa:

Nie ma dowodów wprost na to, lecz jest całkiem możliwe, że Reiss brał bezpośredni lub pośredni udział w zabójstwach zdrajców i osób, które odmówily powrotu do kraju: rezydenta w krajach nadbałtyckich - Ignacego Dziewałtowskiego w końcu 1925 roku; byłego współpracownika radzieckiej agentury w Niemczech - Georga Semmelmanna w czerwcu 1931 w Wiedniu; kuriera Hansa Wissangera w maju 1932 w Hamburgu; jednej z głównych osób nielegalnie przebywających w Austrii - Witolda Sturm de Strome w grudniu 1933 w Wiedniu. Znane mu były także okoliczności zabójstwa byłego rezydenta INO - G. Agabiekowa ${ }^{21}$. Krótko mówiąc, wiedział, czym grozi zdrada ojczyzny i „służby”. Przecież w połowie lat 20. wszyscy wywiadowcy podpisywali specjalne oświadczenie, którego naruszenie przewidywało karę w porządku pozasądowym ${ }^{22}$.

Dodam do tej listy jeszcze dwie sprawy z udziałem Reissa. Chodzi o głośne wydarzenie związane z pozbawieniem życia w sierpniu 1925 roku Władimira Nesterowicza (1895-1925), eksrezydenta wywiadu wojskowego, bohatera wojny domowej. Nesterowicz porzucił swój urząd w Wiedniu i udał się do Niemiec, gdzie nawiązał kontakt $\mathrm{z}$ agentami brytyjskimi. Zwykle opuszczenie urzędu wiązało się z defraudacją środków pieniężnych. Eksrezydent został otruty w restauracji w Mainzu przez agentów Komunistycznej Partii Niemiec, braci Holków. A nieco wcześniej, w 1924 roku, Reiss zaangażował się w tuszowanie skandalu, którego bohaterem był inny agent radziecki o tym samym pseudonimie, co Porecki, czyli „Ludwig”. Reiss wywiózł był wówczas z Berlina do Wiednia kochankę-prostytutkę Ludwiga i ślad po niej skutecznie zaginął. Zapytam retorycznie: czy otwarte wystąpienie przeciwko stalinowskiemu systemowi przez opublikowanie listu otwartego do WKP(b), ucieczka z Paryża do Szwajcarii z zawłaszczonymi rządowymi pieniędzmi może zmazać jego winy?

20 Великие операции спецслужб...

21 Gieorgij/Grigorij Agabiekow (właśc. Gieorgij/Grigorij Arutiunow; 1895-1937) - radziecki funkcjo-nariusz NKWD, jeden z pierwszych wysokich funkcjonariuszy stalinowskich służb specjalnych, który odmówił powrotu do ZSRR. W czerwcu 1930 roku uciekł z Konstantynopola, gdzie był rezydentem INO NKWD, do Paryża. Podjął współpracę z wywiadami wielu państw europejskich. Występował z odczytami i wykładami, w których demaskował system stalinowski. W sierpniu 1937 roku zginął w obszarze nadgranicznym hiszpańsko-francuskim w wyniku zamachu zorganizowanego przez agenta NKWD, Aleksandra Korotkowa (1909-1961), który w przyszłości został generałem KGB i szefem wywiadu zewnętrznego. Przypis - G. O.

22 Великие операции спеислужб... 


\section{7 lipca 1937}

Już wkrótce historia potoczy się dokładnie tak, jak przewidywali to moskiewscy współpracownicy Reissa. Zaraz bowiem, po zakończeniu pokazowych procesów moskiewskich, wybitny wywiadowca został wezwany w sobotę 17 lipca 1937 do ambasady radzieckiej w Paryżu i otrzymał tam polecenie pilnego powrotu do kraju w celu odbycia „osobistych konsultacji” ze swoimi przełożonymi służbowymi. Reiss jednak odmówił wykonania polecenia, ponieważ od dłuższego czasu nosił się już z zamiarem opuszczenia szeregów służb specjalnych, znał ponadto tragiczne losy wielu dyplomatów, współpracowników INO NKWD, a także wojskowych attaché, którzy posłusznie powrócili do ZSRR. Świadomie nie chciał dzielić losu prawdziwych oraz rzekomych szpiegów, wywiadowców, zdrajców radzieckiej ojczyzny i współpracowników z obcymi wywiadami, czyli zginąć po wstępnych torturach i w męczarniach w podziemiach Łubianki ${ }^{23}$. Jelizawieta Porecka była pewna, że gdyby jej mąż dla własnego bezpieczeństwa zgłosił się wtedy dobrowolnie na francuską lub szwajcarską policję jako osoba nielegalnie przebywająca na ich terenie, wówczas „aresztowano by go, oczywiście, za posługiwanie się fałszywymi dokumentami, lecz jest mało prawdopodobne, by w danym przypadku groziła mu surowa kara. W każdym razie, pozostałby wśród żywych. Jego odważne zerwanie z GPU przyniosłoby mu pożądany rozgłos" ${ }^{24}$.

Być może w tę samą sobotę, 17 lipca 1937 roku, po wyjściu z ambasady radzieckiej Reiss napisał swój list adresowany do Komitetu Centralnego Wszechzwiązkowej Komunistycznej Partii (bolszewików), a być może został on napisany już wcześniej, natomiast wezwanie agenta do ambasady uruchomiło lawinę zdarzeń. Wiadomo, że Reiss swój list demaskujący politykę masowych represji Stalina przekazał do opublikowania przez trockistowski „Biuletyn Opozycji”, redagowany i wydawany przez Lwa Siedowa, (1906-1938), syna Lwa Trockiego ${ }^{25}$. Reiss złożył także w ambasadzie radzieckiej ory-

23 Mam na myśli słynny i złowrogi artykuł 58. kodeksu karnego Rosyjskiej Federacyjnej Socjalistycznej Republiki Radzieckiej z 25 lutego 1927 roku z późniejszymi zmianami (zwłaszcza z 1934 roku i po zdefiniowaniu pojęcia „wróg ludu”). Na tej podstawie aresztowano osoby podejrzane o działalność kontrrewolucyjną, karząc zgodnie z czternastoma paragrafami, w których wyspecyfikowano następujące przestępstwa: 1. zdrada Ojczyzny; 2. zorganizowanie powstania zbrojnego, próba przejęcia władzy nad częścią terytorium; 3. udzielanie pomocy wrogom ZSRR; 4. udzielanie pomocy międzynarodowej burżuazji; 5. skłanianie obcego mocarstwa do wypowiedzenia wojny ZSRR; 6. szpiegostwo; 7. działanie na szkodę przemysłu, transportu, handlu, obrotu pieniężnego i spółdzielczości; 8. terror; 9. dywersja; 10. działalność propagandowa wymierzona przeciwko ZSRR; 11. wszelkiego rodzaju działalność zorganizowana nastawiona na przygotowanie lub dokonanie przestępstw przewidzianych $\mathrm{w}$ danym rozdziale, a także udział w organizacji utworzonej w celu przygotowania lub dokonania jednego $\mathrm{z}$ przestępstw, przewidzianych $\mathrm{w}$ niniejszym rozdziale; 12 . niedoniesienie o popełnieniu przestępstwa; 13. służba w oddziałach carskich; 14. sabotaż (ekonomiczna kontrrewolucja). Zob. np.: [Online:] <https://pl.wikipedia.org/wiki/Artykuł_58_(radziecki_kodeks_karny)>; Статья 58 Уголовного кодекса РСФСР (1938); <http://www.gumer.info/bibliotek_Buks/History/ Article/st_58.php> (dostęp: 10.06.2017).

24 Л. Клот. Знакомые лииа: романдиы века на наших странииах | Le général Guisan élu Romand du siècle. [Online:] <http://nashagazeta.ch/news/12648> (dostęp: 1.06.2017).

25 Do dzisiaj nie ustają podejrzenia, że Lew Siedow zmarł na skutek „ukierunkowanej opieki medycznej", jaką otrzymał w jednym ze szpitali paryskich od lekarzy współpracujących z komunistami 
ginał listu z prośbą o jego przekazanie do Moskwy na ręce Lidii Grozowskiej pełniącej funkcję sekretarza przedstawicielstwa handlowego ${ }^{26}$. Czy Reiss wiedział, że Lidia Grozowska od dawna jest agentem NKWD? Można przypuszczać, że nie, w przeciwnym bowiem razie nie popełniłby raczej tak wielkiego błędu i liczyłby się z brakiem lojalności ze strony sekretarza przedstawicielstwa handlowego oraz permanentną perlustracją dokumentów agenturalnych. Można według mnie twierdzić, że list zaadresowany do Komitetu Centralnego Wszechzwiązkowej Komunistycznej Partii (bolszewików) stał się katalizatorem wszystkich wydarzeń, które nastąpiły po dotarciu korespondencji do rąk majora bezpieczeństwa państwowego ${ }^{27}$, zastępcy naczelnika INO NKWD, Siergieja Spiegelglasa (1897-1941), i opublikowaniu jej w najbliższym numerze „Biuletynu Opozycji”.

Oto feralny list Ignacego Reissa, przypominający swoją ekspresją i odwagą pismo księcia Andrieja Kurbskiego (1528-1583), zwanego pierwszym rosyjskim dysydentem, skierowane do cara Iwana IV Groźnego:

Do Komitetu Centralnego Wszechzwiązkowej Komunistycznej Partii (bolszewików)

List, który dzisiaj do Was piszę, powinienem był napisać już dawno, tego dnia, gdy „szesnastu” zostało straconych w piwnicach Łubianki na polecenie „ojca narodów”.

Wtedy milczałem, nie zaprotestowałem także przy następnych zabójstwach i ponoszę za to wielką odpowiedzialność. Ogromna jest moja wina, lecz postaram się ją zmyć, szybko zmyć, aby w ten sposób ulżyć swojemu sumieniu.

Szedłem razem z wami aż do tej pory - teraz ani kroku dalej. Nasze drogi się rozchodzą! Kto teraz jeszcze milczy, staje się wspólnikiem Stalina i zdrajcą sprawy klasy robotniczej oraz socjalizmu.

Od momentu, gdy skończyłem dwadzieścia lat, walczę o socjalizm. Nie chcę teraz, na progu piątego dziesięciolecia, żyć łaskami Jeżowa.

Mam za sobą 16 lat nielegalnej pracy - to nie mało, lecz mam jeszcze dosyć sił, aby zacząć wszystko od nowa. A chodzi właśnie o to, by „zacząć wszystko od nowa”; o to, by uratować socjalizm. Walka zaczęła się już dawno - chcę w niej znaleźć swoje miejsce. Szum, jaki powstał wokół lotników polarnych, powinien zagłuszyć krzyki i jęki męczonych w piwnicach Łubianki, w Swobodnej, Mińsku, Kijowie, Leningradzie i Tyflisie. Do tego nie powinno było dojść. Słowo, słowo prawdy, jest wciąż silniejsze od najmocniejszego silnika o dowolnej liczbie koni mechanicznych.

Zapewne lotnikom-rekordzistom łatwiej jest uzyskać względy amerykańskiej lady i otrutej sportem młodzieży na obydwu kontynentach niż nam zdobyć światową opinię społeczną oraz wstrząsnąć światowym sumieniem! Ale nie trzeba siebie oszukiwać, prawda znajdzie sobie drogę, dzień sądu jest znacznie bliżej, znacznie bliżej niż myślą panowie z Kremla. Bliski jest dzień

\footnotetext{
i Moskwą.

26 Według Walentina Leskowa, Lidia Woroncowa oraz Margarita Woroncowa, a także Lidia Grozowska (1902-1980) to najprawdopodobniej jedna i ta sama osoba, agentka INO NKWD, która brała udział w likwidacji Ignacego Reissa. Ostatnie jej zadanie miało polegać najprawdopodobniej na wynajdowaniu w USA ludzi, którzy mieli wiedzę o uzbrojeniu atomowym. Wśród kochanków Grozowskiej znaleźli się między innymi jeden z synów Fiodora Szalapina, pianista Siergiej Rachmaninow, a także sam Albert Einstein. Zob.: В. Лесков. Сталин и заговор Тухачевского. Москва: Вече, 2003. [Online:] <http://www.e-reading.club/chapter.php/33771/47/Leskov_-_Stalin_i_zagovor_Tuhachevskogo.html> (dostęp: 11.06.2017).

27 Stopień majora NKWD odpowiadał wojskowemu stopniowi dowódcy brygady (комбриг), а więc znajdował się między pułkownikiem a generałem-majorem.
} 
sądu międzynarodowego socjalizmu nad wszystkimi przestępstwami ostatnich dziesięciu lat. Nic nie będzie zapomniane i nic nie będzie przebaczone. Historia jest surową damą i „genialny wódz, ojciec narodów, słońce socjalizmu" będzie musiał odpowiedzieć za wszystkie swoje czyny. Klęska rewolucji chińskiej, czerwone referendum i klęska niemieckiego proletariatu, social-faszyzm i front narodowy, wyznania złożone Howardowi ${ }^{28}$ i czułe gruchanie wokół Lavala ${ }^{29}$; jedna sprawa genialniejsza od poprzedniej! Proces ten zachodzi na oczach ludzi, ma świadków, wielu świadków, żywych oraz martwych; wszyscy oni jeszcze raz przemówią, lecz wtedy powiedzą prawdę, całą prawdę. Zjawią się wszyscy - niewinnie zabici i zniesławieni - a międzynarodowy ruch robotniczy ich zrehabilituje, wszystkich tych Kamieniewów i Mraczkowskich, Smirnowów i Murałowów, Drobnisów i Sieriebriakowów, Mdiwani i Okudżawów, Rakowskich i Ninów ${ }^{30}$, wszystkich tych „szpiegów i dywersantów, agentów gestapo i sabotażystów”.

Aby Związek Radziecki, a razem z nim i cały międzynarodowy ruch robotniczy nie stał się ostatecznie ofiarą otwartej kontrrewolucji i faszyzmu, ruch robotniczy powinien się pozbyć swoich Stalinów i stalinizmu. To mieszanka zrobiona $\mathrm{z}$ - najgorszego, bo pozbawionego zasad oportunizmu, krwią i kłamstwem grozi otruciem całego świata i zniszczeniem resztek ruchu robotniczego.

Najbardziej zdecydowana walka - ze stalinizmem.

Nie front narodowy, lecz walka klasowa; nie komitety, lecz interwencja robotników, aby zbawić hiszpańską rewolucję - oto co znajduje się teraz na porządku dziennym!

Precz z kłamstwem o socjalizmie w jednym kraju - czas powracać do internacjonalizmu Lenina! Ani II, ani III Międzynarodówki nie są zdolne wykonać tej historycznej misji; zdemoralizowane i skorumpowane mogą tylko powstrzymywać klasę robotniczą od walki; one są przydatne jeszcze tylko do tego, by odgrywać rolę pomocników policyjnych burżuazji. Jakaż ironia historii: wcześniej burżuazja dostarczała spośród własnych szeregów Cavaignaców i Galliffetów, Triepowów i Wranglów ${ }^{31}$, a teraz pod „słynnym” kierownictwem obu Międzynarodówek proletariusze sami wykonują pracę katów wobec swoich towarzyszy. Burżuazja może spokojnie zajmować się swoimi sprawami; wszędzie panuje „spokój i ład”; są jeszcze Noske i Jeżowowie, Niegrinowie i Diazowie ${ }^{32}$. Stalin jest ich wodzem, a Feuchtwanger ${ }^{33}$ jest ich Homerem.

28 Niewykluczone, że chodzi o Howarda Hughesa (1905-1976), amerykańskiego miliardera, biznesmena, pilota i konstruktora lotniczego oraz producenta filmowego. W 1935 roku Hughes ustanowił światowy rekord prędkości, który wyniósł 567 km/h, a w 1938 wykonał etapowy lot dookoła świata w czasie 91 godzin. Tu i dalej przypisy do listu Ignacego Reissa pochodzą od autora.

29 Chodzi zapewne o Pierre’a Lavala (1883-1945), francuskiego polityka, który jako przewodniczący parlamentu w trakcie wizyty w Rzymie w 1935 roku zawarł nieformalny układ z Benito Mussolinim, godząc się na zaplanowaną przez duce napaść Włoch na Etiopię. W czasie okupacji niemieckiej był szefem rządu Państwa Francuskiego (Francja Vichy). W trakcie II wojny światowej jako premier prowadził jawną politykę kolaboracji z niemieckim okupantem. Po wojnie został osądzony i skazany na karę śmierci przez rozstrzelanie. Więcej: A. Beevor, A. Cooper. Paris After the Liberation, 1944-1949 (1994); A. Beevor, A. Cooper. Paryż wyzwolony. Tłum. J. Małecki. Kraków: Znak Horyzont, 2015. 30 Ignacy Reiss wymienia nazwiska tzw. starych bolszewików, których Stalin poddał represjom w okresie wielkiej czystki, głównie z obawy o utratę władzy i wpływów w partii.

31 Ignacy Reiss wymienia nazwiska postaci historycznych związanych z określonymi wydarzeniami z przeszłości.

32 Są to nazwiska ludzi wywodzących się z aparatu wykonawczego Stalina, negatywnie zapisanych na kartach historii Rosji.

33 Lion Feuchtwanger (właśc. Jacob Arje; 1884-1958) - niemiecki prozaik i dramatopisarz pochodzenia żydowskiego, autor powieści historycznych oraz popularnych powieści biograficzno-histo- 
Nie, więcej nie mogę. Zwracam sobie wolność. Wracam do Lenina, jego nauczania i sprawy.

Chcę ofiarować swoje skromne siły sprawie Lenina; chcę walczyć i tylko nasze zwycięstwo zwycięstwo rewolucji proletariackiej - uwolni ludzkość od kapitalizmu, a Związek Radziecki - od stalinizmu.

Naprzód ku nowym bojom o socjalizm i proletariacką rewolucję! Za organizację IV Międzynarodówki.

Ludwig (Ignacy Reiss).

17 lipca $1937 \mathrm{r}$.

P. S. W 1928 roku zostałem nagrodzony orderem „Czerwonego Sztandaru” za moje zasługi na rzecz rewolucji proletariackiej. Korzystając z okazji, zwracam wam ten order. Nosić go jednocześnie z katami najlepszych przedstawicieli rosyjskiej klasy robotniczej - poniżej mojej godności.

(W gazecie „Izwiestija” w ostatnich 14 dniach zostały podane nazwiska nagrodzonych orderami; ich funkcje wstydliwie nie były wspomniane: one sprowadzają się do wykonywania wyroków śmierci).

L. $^{34}$

List sam w sobie całkowicie jednoznaczny: odsłaniający prawdę o rzeczywistości okresu stalinowskiego, zwłaszcza zaś wielkiego terroru, a więc niepożądany, niebezpieczny i w konsekwencji... śmiercionośny. Są w nim wydarzenia i ludzie, ich losy oraz akcenty politycznej samowoli i arogancji Stalina, który sprzeniewierzył się ideałom Lenina. Dla takich przesiąkniętych duchem październikowej rewolucji i oddanych sprawie Międzynarodówki Komunistycznej, jak Ignacy Reiss, postępowanie „ojca narodów” było nie do przyjęcia. Stąd jawny bunt i zachęta, by inni szli jego śladem w imię zwycięstwa rewolucji proletariackiej.

Dziś dobrze wiemy, że żadne z oczekiwań Reissa się nie urzeczywistniło, a terror polityczny trwał w ZSRR jeszcze przez dziesięciolecia po śmierci Stalina. Wielu rezydentów, jak Reiss, odmówiło powrotu do ZSRR na wezwanie Kremla. Na przykład Aleksandr Orłow (rezydent w Hiszpanii), Lew Gelfand ${ }^{35}$ (Ambasada ZSRR w Italii) czy Matus Steinberg (Szwajcaria) ${ }^{36}$ opuścili zajmowane rezydentury po cichu, nie afiszując

rycznych i dramatów.

34 Źródło: Изменники и предатели. 1937. РЕЙСС Натан Маркович. [Online:] <http://www. fssb.su/history-state-security/history-state-security-traitors/80-1937-reyss-natan-markovich.html> (dostęp: 31.05.2017). List został opublikowany w 1937 roku, we wrześniowo-październikowym numerze „Biuletynu Opozycji” („Бюллетен оппозиции” [большевиков-ленинцев] 1937, № 58-59, сентябрь-октябрь), s. 23. Zob. także: Военная литература. Мемуары. [Online:] <http://militera. lib.ru/memo/russian/poretskya_ek/01.html> (dostęp: 5.06.2017).

35 Lew Gelfand (1900-?) - z pochodzenia Żyd. Od 1918 roku w Robotniczo-Chłopskiej Armii Czerwonej. Uczestnik wojny domowej, pracownik polityczny. Od 1925 w służbie dyplomatycznej. Pracował w centralnym aparacie Ludowego Komisariatu Spraw zagranicznych ZSRR i jednocześnie służył w INO OGPU NKWD. W 1930 - drugi sekretarz pełnomocnego przedstawicielstwa ZSRR we Francji, W latach 1933-1937 - pierwszy sekretarz, radca pełnomocnego przedstawicielstwa ZSRR we Włoszech. W okresie 1938-1939 - pełnomocnik ds. spraw ZSRR we Włoszech. Od 1940 - uciekinier. Zmarł w USA pod nazwiskiem „Mur”. Na marginesie: syna Mariny Cwietajewej, Gieorgija Efrona, od dzieciństw nazywano Murem.

36 Matus Steinberg (alias Матус/Макс Штейнберг, Матвей Штейнберг, Max Steinberg, Charles Emile Martin/Чарльз Эмиль Мартин/ Шарль Эмиль Мартен; 1904-1987) - Radziecki wywiadowca nielegalnie przebywający w Szwajcarii, major bezpieczeństwa państwowego (1935), członek 
się swoim postępowaniem, lecz zabrawszy pieniądze, którymi dysponowali, udawali się do wybranych państw, z dala - jak sądzili - od europejskich agentów NKWD. Reiss wybrał natomiast rozwiązanie przypominające efekt meteoroidu, który pozostawia po sobie jasny ślad, gdy przelatuje przez atmosferę ziemską.

W relacji Waltera Kriwickiego (1899-1941) ${ }^{37}$, dni bezpośrednio poprzedzające wydarzenia z 17 września 1937 i zaraz po nim, a związane z Ignacym Reissem, wyglądały następująco:

1. Kriwicki przyjeżdża do Paryża w pierwszej połowie lipca 1937 i spotyka się na kilka minut z Reissem 17 lipca o godzinie 19 w kawiarni „Weber”. Reiss prosi o kolejne spotkanie. Umawiają się, że Reiss zadzwoni w tej sprawie do Kriwickiego 18 lipca o godzinie 11.

2. O godzinie 21 Kriwicki zostaje pilnie wezwany do paryskiego biura na rozmowę z Siergiejem Spiegelglasem, który przybył z Moskwy z supertajną misją i nadzwyczajnymi pełnomocnictwami, by zorganizować porwanie generała Jewgienija Millera oraz zlikwidować Ignacego Reissa. Spiegelglas daje Kriwickiemu do przeczytania dwa listy, które tego dnia Reiss przekazał Lidii Grozowskiej. Kriwicki uświadamia sobie, że list Reissa datowany 17 lipca 1937 musiał być napisany przed ich spotkaniem w kawiarni „Weber”. Spiegelglas bezceremonialnie przypomina Kriwickiemu, że odpowiada moralnie za Reissa, ponieważ rekomendował go na członka partii i zaproponował włączenie do agentury. Dlatego, by zmyć swoją winę przed Stalinem, powinien zlikwidować Reissa jeszcze tej nocy w celu uniemożliwienia mu ucieczki z kraju.

3. Kriwicki odmawia wykonania zadania i zdaje sobie od razu sprawę, że jego praca na rzecz wywiadu radzieckiego w tej samej chwili się skończyła, ponieważ nie odpowiadał już wymaganiom ery stalinowskiej, w której pozbawianie innych życia stało się standardowym sprawdzianem na wierność „ojcu narodów”. Wobec odmowy Kriwickiego Spigelglas wzywa na wspólną rozmowę innego agenta o pseudonimie „Mann”, czyli Teodora Mally'ego ${ }^{38}$, przyjaciela Reissa.

sieci agenturalnej pod kryptonimem „Czerwona Orkiestra” w Szwajcarii. Kodowe identyfikatory: przedsiębiorca z Harbinu i szwajcarski inżynier George Wilmer, Lorenz, Laurenz, Dubois oraz: mediolański przemysłowiec Carlo Emilio Wilmer.

37 Walter Kriwicki (właśc. Samuel Ginzberg; 1899-1941) - oficer radzieckiego wywiadu wojskowego, rezydent INO NKWD na Europę Zachodnią w latach 1935-1937. Po tym, jak odmówił powrotu do ZSRR, wyemigrował do USA, gdzie rozpoczął intensywną pracę demaskatorską, której celem było obnażenie totalitarnego systemu stalinowskiego i radzieckiego wywiadu agenturalnego. W kwietniu 1939 roku, na kilka miesięcy przed zawarciem tajnego aktu Ribbentrop-Mołotow, Kriwicki pisał o konsekwentnym dążeniu Stalina do porozumienia z III Rzeszą. Według niektórych źródeł stał się kolejną ofiarą zabójstwa dokonanego przez agentów NKWD, według innych - że popełnił samobójstwo. Kriwicki, tak samo jak Porecki-Reiss, urodził się w Podwołoczyskach.

38 Theodor Mally (1894-1938) - były ksiądz katolicki, który stał się radzieckim wywiadowcą, majorem bezpieczeństwa państwowego. Studiował w Wiedniu na wydziałach filozoficznym oraz teologicznym. Członkiem partii bolszewickiej został w styczniu 1920 roku. Uczestnik wojny domowej. W organach służb specjalnych - od 1921 roku, a od 1926 - w organach centralnych OGPU. W latach 30. - współpracownik INO NKWD. Kierownik nielegalnej rezydentury angielskiej. Zajmował się głównie werbowaniem do pracy agenturalnej studentów Oxfordu, mając w tym zakresie określone sukcesy. W lipcu 1937 roku został wezwany do Moskwy. Aresztowany 7 marca 1938. Oskarżony na 
4. Po północy, a więc już w niedzielę 18 lipca 1937, Kriwicki dzwoni parokrotnie do Reissa i odkłada słuchawkę upewniwszy się, że odebrał on telefon. Między godziną pierwszą a trzecią w nocy Kriwicki z Mannem dzwonią do Reissa jeszcze czterokrotnie w taki sam sposób: głuche telefony były sygnałem ostrzegawczym.

5. Po godzinie 10 rano 18 lipca 1937 roku dochodzi do spotkania Kriwickiego i Manna ze Spiegelglasem. Przyjaciele Reissa dowiadują się, że Reiss zdołał uciec.

6. Rankiem 19 lipca 1937 Kriwicki otrzymuje list od Reissa, w którym ten żegnał się z nim i wyjaśniał powody swojego postępowania, a z rana 20 lipca 1937 Spiegelglas żąda od Kriwickiego pilnego spotkania w sprawie listu, jaki ten otrzymał od Reissa. Kriwicki oddaje ten list Spiegelglasowi ${ }^{39}$.

$Z$ relacji Kriwickiego płyną co najmniej dwa istotne wnioski w kontekście sprawy Reissa: po pierwsze, że Reiss napisał swój list do KC WKP(b) przed godziną 19, tj. przed spotkaniem z Kriwickim, a po drugie, że polowanie na agenta-uciekiniera rozpoczęto jeszcze tego samego dnia, w którym Reiss pozostawił swoje listy pracownicy ambasady ZSRR w Paryżu, Lidii Grozowskiej. We wspomnieniach Kriwickiego zostały także ujawnione szczegóły dotyczące typowania osób do wykonania wyroku śmierci na Reissie. Ponieważ Kriwicki i Mally odmówili wykonania zadania, Spiegelglas zdecydował się na grupę Siergieja Efrona; Efron nie odmówił.

Spiegelglas zameldował o sprawie Nikołajowi Jeżowowi (1895-1940), szefowi NKWD. Jeżow - Stalinowi. Stalin, urażony postępkiem Reissa, nie mógł się pogodzić z jawną krytyką jego samego i jego polityki. Życie innego człowieka nie miało dla „ojca narodów” żadnego znaczenia, czego niejednokrotnie dowiodła historia, więc jeszcze jeden wyrok śmierci wydany na tego, który mu dotąd wiernie służył, oznaczał wyłącznie powiększenie danych statystycznych i dawał poczucie dobrze spełnionego obowiązku... Ze słów Aleksandra Orłowa ${ }^{40}$ (1895-1973) wiadomo, że „gdy zameldowano Stalinowi o «zdradzie Reissa», ten wydał rozkaz Jeżowowi, by zlikwidował zdrajcę, razem z jego żoną i synem. Miało to być pokazowe ostrzeżenie wobec wszystkich potencjalnych osób, które odmówiły powrotu” do ZSRR ${ }^{41}$. „To było oczywiste - pisze

podstawie artykułu 58. wspomnianego kodeksu karnego RFSRR z 25 lutego 1927 roku. Rozstrzelany 20 września 1938. Zrehabilitowany w 1956 roku. Zob. jeszcze: Л. Млечин. История внешней разведки..., s. 388.

39 Rekonstrukcja na podstawie książki Waltera Kriwickiego: В. Кривицкий. Я был агентом Статина. Записки советского разведчика. Москва: Tерpа-Terra, 1991. [Online:] <https://scepsis.net/ library/print/id_559.html> (dostęp: 12.06.2017).

40 Aleksandr Orłow (właśc. Lew/Lejba Feldbin; 1895-1973) - major bezpieczeństwa państwowego ZSRR (1935). W NKWD nosił pseudonim Lew Nikolski (Лев Никольский), a w USA - Igor Berg (Игорь Берг). W latach 1933-1937 był nielegalnym rezydentem zagranicznego oddziału NKWD (INO NKWD) we Francji, Austrii i Włoszech, a legalnym rezydentem NKWD i radcą rządu republikańskiego ds. bezpieczeństwa w Hiszpanii w latach 1937-1938. Wezwany na spotkanie z przedstawicielem INO w czasie wielkiej czystki, przewidując uprowadzenie i egzekucję w przypadku wykonania rozkazu, wyjechał do Stanów Zjednoczonych Ameryki Północnej wraz z dokumentacją i kasą rezydentury NKWD w Hiszpanii. Autor wspomnień demaskujących kulisy wielkiej czystki, opublikowanych po śmierci Stalina. Na obczyźnie wykładał w uniwersytetach amerykańskich.

41 W języku rosyjskim mianem „невозвращенец” nazywano obywateli ZSRR, a także poddanych Imperium Rosyjskiego, którzy odmówili powrotu do kraju, przebywając legalnie na prywatnym wy- 
Ludmiła Kłot - że po skandalicznym zerwaniu [ze Stalinem - G. O.] dni jego [Reissa - G. O.] były policzone" 42 .

\section{Między 17 lipca 1937 a 4 września 1937}

Reiss uciekł z Paryża 18 lipca 1937 roku najpierw na krótko do Holandii, po czym schronił się razem z żoną i 12-letnim synem Romanem w Szwajcarii, w głuchej wsi Finhaut, położonej w kantonie Valais. Tam Reissowie przebywali około miesiąca, by przenieść się do kantonu Vaud. A jeszcze później, w dniu zabójstwa, przeprowadzili się do maleńkiej miejscowości pod Lozanną - Territet. Reiss krążył jeszcze po ucieczce między Paryżem i Lozanną, mając nadzieję na pierwsze spotkanie z Lwem Siedowem. Zerwanie Reissa z reżimem stalinowskim pozytywnie odebrał Lew Trocki, któremu były już agent służb specjalnych przekazał informacje o szykowanym na niego zamachu. O trudnym okresie ukrywania się przed światem w Szwajcarii Jelizawieta Porecka wspominała: „Jesteśmy wolni, lecz to oznacza zerwanie ze wszystkim, co sercu drogie: z młodością, z przeszłością, z towarzyszami. W krótkim czasie Ludwig bardzo się postarzał, włosy mu zbielały, a dusza jego znajduje się w podziemiach Łubianki. Jeśli nawet uda się mu zasnąć, widzi we śnie egzekucje lub samobójstwa"43.

Ucieczka Reissa wywołała reakcję łańcuchową: Spiegelglas polowanie na Lwa Siedowa, którym zajmowała się dotąd grupa Siergieja Efrona, przekształcił natychmiast w polowanie na Ignacego Reissa i wzmocnił siły agenturalne, angażując do poszukiwania zdrajcy zasłużoną dla Kremla grupę agenta Jakowa Sieriebranskiego. Do całej akcji zaangażowano prawie dwadzieścia osób, sama zaś operacja kosztowała rząd radziecki około 300000 franków, a więc bardzo dużo, jak na ówczesne warunki życia we Francji ${ }^{44}$.

Wybór agentów z Paryża jako wykonawców zadania nie był dziełem przypadku, tutaj bowiem urywał się ślad Reissa. „Związkiem Powrotu do Ojczyzny” kierował w tamtym czasie Siergiej Efron, a wspierała go między innymi fanatyczna komunistka i agentka INO NKWD, Wiera Guczkowa-Traill (1906-1986), również zamieszana w sprawę zabójstwa Poreckiego ${ }^{45}$. Zdaniem Ludmiły Kłot, Efron „bezpośredniego udziału w rozprawie nie miał, ale zajmował się kwestiami organizacyjnymi i koordynował śledzenie wywiadowcy-zdrajcy" ${ }^{46}$. Czy jednak wszyscy zorientowani w danej sprawie uważają tak samo? Niekoniecznie.

Siergiej Efron został agentem NKWD w 1934 roku. Działał pod przykryciem jako generalny sekretarz „Związku Powrotu do Ojczyzny”. Kierował kilkuosobową gru-

jeździe zagranicznym czy w ramach delegacji. Oficjalnie zjawisko nielegalnej emigracji z państwa totalitarnego w latach 30. XX wieku definiowano w ZSRR prawnie jako „ucieczka w czasie pobytu za granicą".

42 Л. Клот. Игнатий Рейсс..

43 Л. Клот. Игнатий Рейсс...

44 Taką kwotę wymienia Walter Kriwicki. Zob. B. Кривицкий. Я был агентом Сталина..., s. 265.

45 Informację tę znalazłem na następującej stronie: Гучкова-Трэйл Вера Александровна. [Online:] $<$ http://rusrazvedka.narod.ru/base/htm/guct.html> (dostęp: 9.06.2017).

46 Л. Клот. Игнатий Рейсс... 
pą, w której była także Renata Steiner. W 1931 roku mąż Cwietajewej złożył wniosek o paszport radziecki i deklarację gotowości do współpracy z organami NKWD, byleby tylko odkupić swoje winy wobec ojczyzny. NKWD chętnie dało szansę, a kolejna brudna sprawa, którą załatwił Efron sam lub zespołowo szła na poczet zmazywania win. Jak pisze Rogowin, „Efron i jego przyjaciele ze «Związku» brali udział w najbrudniejszych zagranicznych operacjach NKWD" ${ }^{47}$. Praca agenturalna Efrona musiała przynosić określone efekty, skoro w domu pojawiały się odtąd regularnie setki franków na utrzymanie rodziny. Cwietajewa była przecież bystrą kobietą i doskonale zdawała sobie sprawę, skąd pochodzą środki finansowe, które regularnie przynosił bezrobotny mąż.

\section{4 września 1937}

Według Waltera Kriwickiego, dnia 4 września 1937 roku Gertruda Schildbach (1896-1941) ${ }^{48}$ i obywatel Monako Rol(l)and Abbiate (alias Władimir Prawdin, ps. „Pilot”; 1904-1970), agent NKWD należący do Zarządu Zadań Specjalnych, wynajęli pokój w Hôtelu de la Paix w Lozannie ${ }^{49}$. Schildbach, kilkuletnia współpracownica Reissa jeszcze w okresie lipskim i przyjaciółka domu Poreckich, nie wiedziała, że Abbiate w związku ze sprawą zabójstwa Reissa odgrywa od pewnego czasu rolę płomiennego kochanka wyłącznie na polecenie NKWD. Po zakończeniu akcji Schildbach i Abbiate nie powrócili już do hotelu i nie zapłacili rachunku za pobyt. Pozostawili jednak w wynajmowanym pokoju swój prywatny bagaż, który odegrał w śledztwie określoną rolę; zwłaszcza nadziane strychniną czekoladki ${ }^{50}$. Zakończył się też „służbowy związek" dwojga szpiegów.

47 В. 3. Роговин. Прозрение и гибель Игнатия Райса. В: В. 3. Роговин. 1937. Москва: (brak danych o wydawnictwie), 1996. [Online:] <http://www.litres.ru> (wersja PDF, s. 678) (dostęp: 11.06.2017). Grupa operacyjna Siergieja Efrona przygotowywała w styczniu 1937 roku zamach na życie Lwa Siedowa w Miluzie, mieście położnym w północno-wschodniej Francji.

48 Gertruda Schildbach (z d. Neugebauer) urodziła się w niemieckim Strasburgu. Żydówka. Wykształcenie wyższe humanistyczne, nauczycielka języków obcych. Po 1933 roku uciekła z Niemiec do Rzymu, gdzie była nielegalnym rezydentem NKWD. Aresztowana 1 VII 1941. Zrehabilitowana 8 X 1941. [Online:] <https://nekropole.info/ru/Gertruda-Shildbah> (dostęp: 11.06.2017).

49 W książce Waltera Kriwickiego mówi się о Отеле де ля Пэж, co należałoby oddać po francusku jako Hôtel de la Paige. Niewykluczone, że Kriwicki się pomylił. Zob.: В. Кривицкий, Я был агентом Сталина..., s. 265. Z kolei William E. Duff wskazuje na dzień 3 września 1937 jako datę zameldowania się Schildbach i Abbiate'a w Hôtelu de la Paix. Zob.: W. E. Duff. A Time for Spies: Theodore Stepanovich Mally and The Era of The Great Illegals. Nashville and London: Vanderbilt University Press, 1999, s. 168.

50 To o operacyjnym przeznaczeniu pudełko nadzianych strychniną czekoladek przywiozła z Paryża do Lozanny Renata Steiner i przekazała je Gertrudzie Schildbach. Pisze o nich także Walter Kriwicki jako dowodzie w sprawie zabójstwa Reissa i poszlakach prowadzących do Gertrudy Schildbach. Zob.: В. Кривицкий. Я был агентом Сталина..., s. 264. Na marginesie: służby NKWD chętnie sięgały po pudełka z czekoladkami, by pozbawić człowieka życia. Tak zginął między innymi 23 maja 1938 roku w Rotterdamie przywódca OUN, Jewhen Konowalec, któremu agent NKWD, Paweł Sudopłatow (1907-1996), wręczył bombonierkę z ładunkiem wybuchowym, przygotowanym wcześniej 
Dnia 4 września 1937 roku Reiss, odpowiadając wcześniej na rozpaczliwy i pełen wątpliwości list Schildbach, przebywającej wtedy w Rzymie, zgodził się z nią spotkać w Lozannie. Od pewnego czasu przełożeni Schildbach nie mieli do niej pełnego zaufania, była zatem politycznie niepewna, a w rozmowach z Reissem wyrażała gotowość wspólnego opuszczenia agenturalnych szeregów. O złym stanie ducha Schildbach byli doskonale poinformowani także urzędnicy najwyższych organów NKWD, którzy postanowili teraz z tej wiedzy zrobić perfidny użytek. Reiss bezgranicznie ufał Schildbach i, odpowiadając na jej korespondencję, ujawnił czas oraz miejsce kontaktu, postąpił zatem bardzo nieprofesjonalnie, jak na agenta o tak wysokich kwalifikacjach, powinien był bowiem zdawać sobie sprawę, że pościg za nim już na pewno trwa, a dotychczasowi przyjaciele mogą się okazać członkami grupy likwidatorskiej NKWD.

Czy wiemy dokładnie, jak wyglądały ostatnie godziny życia Reissa i sam przebieg zabójstwa? Niestety, tylko częściowo, gdy dokonamy określonych rekonstrukcji, opierając się na materiałach zebranych w trakcie śledztwa, jakie prowadziły odpowiednie organy w Szwajcarii i we Francji. Zasadniczą wartość dowodową posiadają tutaj zeznania Jelizawiety Poreckiej oraz Renaty Steiner.

Z początku 4 września 1937 roku miało dojść do pozbawienia Reissa życia przez otrucie go czekoladkami nadzianymi strychniną. Gertruda Schildbach spotkała się najpierw z Poreckimi po południu w jednej z lozańskich kawiarni i w sposób naturalny rozpoczęła przekazywanie śmiertelnego prezentu, kierując go w stronę żony Reissa. Najprawdopodobniej w ostatnim momencie Schildbach uświadomiła sobie, że tymi samymi czekoladkami mogą się także otruć członkowie rodziny Reissa i dlatego zachowała się w sposób dziwny dla Poreckich, wyrywając gwałtownie pudełko ze słodyczami z rąk żony Reissa, jednocześnie przepraszając, że musi już iść, podawszy za powód pilne spotkanie w innym miejscu. Wyznaczono zatem godzinę kolejnego spotkania: wieczorem w jednej z lozańskich restauracji. Na drugie spotkanie z Schildbach Reiss przybył już bez żony. Spiegelglas, który przewidział różne warianty przebiegu zdarzenia, wysłał do restauracji, w której miało dojść do spotkania Poreckiego z Schildbach, dwóch agentów: Borysa Afanasjewa i Władimira Prawdina ${ }^{51}$.

Ze zrozumiałych względów nie dysponujemy dzisiaj dokładnymi danymi o przebiegu zdarzeń, które doprowadziły do zgonu Reissa. Na chwilę obecną dwie wersje należą do najbardziej znanych. Zgodnie z pierwszą, w pewnym momencie miało dojść w restauracji do zainscenizowanej kłótni, a „pijanego” czy raczej odurzonego Reissa, by uniknąć skandalu, Prawdin i Afanasjew „wyprowadzili” w towarzystwie Schild-

specjalnie na tę okazję przez specjalistów z działu technicznego NKWD. Sudopłatow był przyjacielem Siergieja Spiegelglasa. Przygotował udany zamach na Lwa Trockiego. Współorganizator szpiegostwa atomowego.

$51 \mathrm{~W}$ artykule Великие операции спецслужб..., opartym na wspomnieniach Pawła Sudopłatowa, mówi się o tym, że zarówno Afanasjew, jak i Prawdin byli Bułgarami, co nie znajduje potwierdzenia $\mathrm{w}$ innych tekstach przedmiotowych, ponadto o Prawdinie pisze się tutaj błędnie jako o Wiktorze Prawdinie, zięciu Afanasjewa, a o Renacie Steiner jako kochance Prawdina. W konfrontacji z pozostałymi źródłami należy raczej przyjąć, że Renata Steiner mogła być albo nawet była zarówno kochanką Siergieja Efrona, jak też Władimira Prawdina i wielu innych mężczyzn, jednak Prawdin nie był Bułgarem i z uwagi na swój rok urodzenia (1904), jak również rok urodzenia Afanasjewa (1902) nie mógł być absolutnie zięciem drugiego agenta. 
bach, wsadzili do samochodu i odjechali. Zabiwszy po drodze, ciało porzucili w przydrożnych krzakach. Według drugiej wersji, cała czwórka - Reiss, Schildbach oraz dwaj wymienieni agenci - dobrowolnie i w spokoju opuścili restaurację, wsiedli do auta i udali się w nieznanym kierunku.

W każdej z powyższych wersji pojawia się moment wsiadania do pojazdu i oddalenia agentów-zabójców oraz ofiary z miejsca egzekucji. Powstaje jednak pytanie, co było dalej? Czy do zabójstwa doszło już w samochodzie czy też Reissa przed śmiercią zamierzano jeszcze przesłuchać, aby wyjaśnić kwestie, jakie interesowały ludzi Jeżowa i Spiegelglasa? Stawiałbym raczej na tę właśnie opcję, chociażby dlatego, że strzelanie do żywej krępej, a więc zapewne i silnej fizycznie osoby w aucie nie zawsze jest łatwe i bezpieczne, jeśli ofiara siedzi na przykład między dwoma oprawcami na tylnym siedzeniu, ponadto, jeśli w ciele denata odnaleziono wiele ran postrzałowych w okolicach klatki piersiowej, to oddanie wszystkich strzałów nie mogło raczej nastąpić wewnątrz auta: zabójca siedzący na miejscu pasażera z przodu, jeśli strzelał do Reissa, musiałby się najpierw odwrócić $\mathrm{w}$ jego kierunku, być może unieść $\mathrm{z}$ siedzenia, wycelować, strzelić i przy okazji nie zranić asystujących w zamachu dwóch pozostałych agentów siedzących obok Reissa.

Walter Kriwicki podaje jeszcze inną możliwość:

On [Reiss - G. O.] pojechał z nią [Schildbach - G. O.] na obiad w restauracji w pobliżu Chamblandes, by omówić sytuację. Tak myślał Reiss. Po obiedzie poszli na krótki spacer. W czasie spaceru wyszli na głuchą drogę. Nagle zjawil się samochód i gwałtownie zahamował. Wyskoczyło z niego kilku mężczyzn, którzy napadli na Reissa. Reiss próbował się bronić. Z pomocą Schildbach, której pęk włosów pozostał w zaciśniętej dłoni zabitego, napastnikom udało się wepchnąć go do auta. Jeden z ludzi - Abbiate-Rossi - razem z innym agentem OGPU, wezwanym z Paryża, Étiennem Martigny ${ }^{52}$, wystrzelił do Reissa z bliskiej odległości. Jego martwe ciało wyrzucono z samochodu niedaleko od tego miejsca. ${ }^{53}$

Tak samo, jak u Kriwickiego, jest w książce Leonida Mleczina Historia wywiadu zewnętrznego. Kariery i losy (История внешней разведки. Карьеры и судьбы), który, jak widać, powtarza zasadniczo wersję Kriwickiego:

W trakcie śledztwa, związanego z zabójstwem Poreckiego, policja szwajcarska ustaliła, co następuje.

Nocą [z 3 - G. O.] na 4 września $1937^{54}$ roku w pewnej odległości od drogi, która prowadziła z Lozanny do Chamblandes, zostało odnalezione ciało nieznanego mężczyzny w wieku około lat czterdziestu. Pięć kul wsadzono mu w głowę, siedem w ciało ${ }^{55}$. Policja szybko odnalazła

52 Étienne/Charles Martigny i Borys Afanasjew (Atanasow; 1902-1981) to najprawdopodobniej jedna i ta sama osoba - Bułgar, agent NKWD, a w niedalekiej przyszłości - sowiecki pułkownik (od 1953) i jeszcze później - zastępca redaktora naczelnego czasopisma „Literatura Radziecka” („Советская литература" 1963-1965). Przypis - G. O.

53 В. Кривицкий. Я был агентом Сталина..., s. 265.

54 Jeśli przyjąć, że zegarek Reissa, na którym wskazówki zatrzymały się na godzinie 9.40 (= 21.40) wskazywały czas zabójstwa, wówczas do zamachu na życie nie mogło dojść w nocy z 3 na 4 września 1937 roku. Przypis - G. O.

55 Na marginesie: gdyby ran postrzałowych było trzynaście - w układzie $5+8-$ można byłoby się dopatrzeć w liczbie 58 zbieżności z artykułem 58. kodeksu karnego RFSRR (1925 z późn. zm.), na 
porzucone auto ze śladami krwi w kabinie i aresztowała kobietę, która wypożyczyła samochód. Ku zdziwieniu policji, nie usiłowała ona się ukryć po dokonaniu zabójstwa.

Ta kobieta nazywała się Renata Steiner i nie mogła zrozumieć, gdzie się podziali jej przyjaciele, którym przekazała to auto. Policja zidentyfikowała „przyjaciół” Steiner i stworzyła wersję prawdopodobnego przebiegu zdarzeń. Ale nikogo, prócz Renaty Steiner, policji się nie udało odnaleźć. Zakłada się, że moskiewskiej grupie operacyjnej pomogła Gertruda Schildbach (z d. Neugebauer), członkini Komunistycznej Partii Niemiec, która uciekła z kraju po objęciu władzy przez nazistów.

Schildbach przyjaźniła się z Poreckim. Policja doszła do wniosku, że Schildbach namówiła Poreckiego na spotkanie. Razem pojechali do restauracji za miastem. Po obiedzie wyszli na spacer i wtedy na mało uczęszczanej drodze pojawił się samochód, z którego wyskoczyło kilku mężczyzn $^{56}$. Na siłę wepchnęli Poreckiego do auta, w którym go zastrzelili. Zwłoki wyrzucili na drogę.

Renata Steiner wymieniła nazwisko Efrona. Według niej był on agentem NKWD. ${ }^{57}$

Biorąc powyższe wersje pod uwagę, wydaje się mi, że najbliżej prawdy był jednak Kriwicki, który doskonale znał metody operacyjne NKWD i technikę niespodziewanego nalotu samochodowego, by zastrzelić ofiarę i tak samo szybko się oddalić w tylko sobie znanym kierunku. Lecz w narracji Kriwickiego nic się nie mówi o pęku siwych włosów należącym do Gertrudy Schildbach. Dlatego uzupełniam to brakujące ogniwo przez logiczny domysł, który może odpowiadać rzeczywistemu przebiegowi zdarzenia, może się też z prawdą całkowicie lub częściowo mijać. Tak więc, ostatnie godziny życia Reissa mogły wyglądać następująco:

1. Schildbach i Reiss spokojnie opuszczają restaurację i udają się w plener, aby uniknąć potencjalnych podsłuchów. Ścieżkę spacerową proponuje Schildbach, a niczego niepodejrzewający Reiss nie oponuje.

2. Gdy Schildbach i Reiss wychodzą na mało uczęszczaną drogę. Kobieta wie, że za chwilę zjawi się samochód, a z niego wysiądą zabójcy Reissa.

3. Gdy z samochodu wysiada czworo mężczyzn, Reiss orientuje się, że wpadł w pułapkę i że Schildbach nie jest tutaj bez winy.

4. Reiss próbuje się bronić, traktując Schildbach jak żywą tarczę. Kobieta krzyczy i się wyrywa, lecz Reiss wie, jak skutecznie należy trzymać człowieka, jedną ręką unieruchamiając jego tułów, a drugą trzymając mocno za włosy.

5. Następuje, być może, szybka i ostra wymiana zdań pomiędzy zabójcami a Reissem. Reiss nie godzi się na dobrowolne wypuszczenie Schildbach. Wtedy padają pierwsze strzały od tyłu, które trafiają Reissa w tułów; potem następne.

6. Reiss pod wpływem postrzałów upada i uwalnia tym samym z uścisku Schildbach, która z uwagi na swoje słabe nerwy, niewykluczone, że wpada w histerię. W prawej dłoni Reissa pozostaje pęk siwych włosów zdrajczyni.

którego podstawie skazywano „wrogów ludu”. Przypis i pogrubienie - G. O.

56 Ale ta wersja nie uwzględnia wyrwania siwych włosów z głowy Schildbach, a włosy przecież były dowodem w sprawie o zabójstwo.

57 Л. Млечин. История внешней разведки. Карьеры и судьбы. [Online:] <https://books.google. pl/books> (dostęp: 10.06.2017). 
7. Zabójcy - czterech mężczyzn i Schildbach - oddają jeszcze pięć strzałów w okolice głowy już martwego Reissa, po czym upychają jego zwłoki do auta i wszyscy oddalają się pośpiesznie z miejsca zdarzenia.

8. Po drodze zabójcy zatrzymują się, wyciągają zwłoki Reissa z auta, wloką ku gęstym zaroślom i porzucają je w takim miejscu od drogi, by nie były widoczne w świetle samochodowych reflektorów, po czym pośpiesznie odjeżdżają z miejsca przestępstwa w kierunku Genewy. Przed stacją kolejową porzucają auto.

Każdy z dwunastu oddanych w kierunku Reissa strzałów mógł być śmiertelny, lecz na modłę zbrodniczych pieczęci NKWD należało się upewnić, że ofiara nie żyje, dlatego zapewne cała piątka oprawców celuje i strzela jeszcze w okolice głowy Reissa. Teraz sprawa jest na pewno skończona: agent nie żyje, a jego zwłoki nie mają dla zabójców żadnego znaczenia. Niewykluczone, że któryś z nich wykonuje jeszcze fotografię pośmiertną Reissa, by okazać ją w Moskwie jako dowód pomyślnego zakończenia akcji: to też jeden z nieludzkich zbrodniczych standardów technicznych NKWD, który, być może, do dzisiaj jest przechowywany w archiwach Łubianki.

Na dzień dzisiejszy wiele wskazuje na to, że pasażerami auta, którym przyjechali zabójcy, byli: Rol(l)and Abbiate, Borys Afanasjew, Wadim Kondratjew i Dmitrij Smirienski. Wśród nich do najbardziej zasłużonych dla stalinowskiego reżimu należy dwóch pierwszych - Abbiate i Afanasjew, to oni bowiem 13 listopada 1937 roku na mocy dekretu Wszechrosyjskiego Centralnego Komitetu Wykonawczego zostali odznaczeni orderami Czerwonego Sztandaru za ofiarne wykonanie zadań specjalnych Rządu Radzieckiego. Rol(l)and Abbiate otrzymał nawet radzieckie obywatelstwo i nową tożsamość paszportową: stał się odtąd Władimirem Siergiejewiczem Prawdinem i dalej zajmował się działalnością agenturalną. Z uwagi na to, że Wadim Kondratjew (19031939), zwerbowany do pracy agenturalnej przez Nikołaja Klepinina w połowie lat 30., pracował w Paryżu nie tylko jako roznosiciel chleba czy pomocnik zecera ${ }^{58}$, lecz jako taksówkarz, można zasadnie przyjąć, że to właśnie on kierował samochodem użytym do akcji związanej z zabójstwem Reissa. On też jako pierwszy ze wszystkich uciekł do ZSRR po zakończeniu zbrodni. Z relacji Dmitrija Sezemana (1922-2010) wynika, że Wadim Kondratjew jako jedyny z grupy uczestniczącej w zabójstwie Ignacego Reissa nie został poddany represjom, ponieważ zachorował na gruźlicę i zmarł w Moskwie. „W ten sposób prątki Kocha wygrały z NKWD” - ironizował Sezeman ${ }^{59}$.

58 W tej samej paryskiej drukarni, której właścicielem był niejaki Borys Schwarz, pracował Nikołaj Klepinin jako administrator, Siergiej Efron zajmował się korektą, a Wadim Kondratjew wykonywał czynności zecera. Zob. nр.: Б. Прянишников. Незримая паутина: ОГПУ-НКВД против белой эмиграции. Москва: Яуза-Эксмо, 2004, s. 96. [Online:] <https://unotices.com/book.php?i$\mathrm{d}=178320$ \&page $=96>($ dostęp: 17.06 .2017$)$.

59 Zоb.: Б. Носик. Сент-Женевьев-де-Буа. Русский погост в предместье Парижа; <https:// books.google.pl/books> (dostęp: 17.06.2017) - nekrolog: Де Планьи (De Plagny). Юрий Филлипович, 6.01.1905-4.08.1986. Zob.: М. Соколов. Дмитрий Сеземан: Марина Цветаева, Георгий Эфрон и возвращение в СССР. Часть 1. [Online:] <https://www.svoboda.org/a/262693.html > (dostęp: 17.06.2017). Zob. także: Д. П. Прохоров, О. И. Лемехов. Перебежчики. Заочно расстреляны. [Online:] <http://coollib.com/b/271956/read> (dostęp: 17.06.2017). 


\section{Po 4 września 1937}

Jak pisze Walter Kriwicki, „Zabójstwo Reissa stało się głośną sprawą w Europie i wieści o nim dotarły do prasy amerykańskiej oraz innych państw. Policja szwajcarska przy pomocy posła Sneevlieta i wdowy Reissa przeprowadziła solidne śledztwo, które ciągnęło się przez wiele miesięcy. Sprawozdanie ze sprawy zostało włączone do książki, która pojawiła się we Francji w zeszłym roku pod tytułem Zabójstwo Ignacego Reissa i którą opublikował Pierre Tisnét" ${ }^{60}$. Sam Kriwicki dowiedział się o śmierci Reissa już 5 września 1937 roku i wtedy, jak wspomina, „zrozumiał, że moje własne położenie jest rozpaczliwe. Wiedziałem, że Stalin i Jeżow nie wybaczą mi udziału w sprawie Reissa. Przede mną był wybór - albo kula na Łubiance z rąk oficjalnych katów, albo seria z pistoletu maszynowego wypuszczona przez tajnych stalinowskich zabójców poza granicami Rosji”61.

Za punkt wyjścia w zrelacjonowaniu najnowszej wiedzy o zamachu na życie radzieckiego szpiega wybrałem artykuł Ludmiły Kłot, jaki ukazał się 14 września 2012 roku na łamach szwajcarskiej „Naszej Gazety”, która za gazetą „24 Heures” przypomniała tamtejszym czytelnikom o zdarzeniu historycznym (wtedy) sprzed 75 lat. Dany tekst nie jest kompletnym źródłem i wymaga uzupełnień literaturowych, ale porządkuje pewne sprawy w sposób klarowny i dostarcza informacji, których nie znajduję $\mathrm{w}$ innych opracowaniach przedmiotowych.

Tak więc, z dokumentacji śledczej, o której wspomina Kłot, wynika, że wczesnym rankiem 5 września 1937 roku jeden z mieszkańców dzielnicy Chamblandes w miasteczku Pully pod Lozanną, będąc na spacerze z psem, natknął się na pozbawione oznak życia zakrwawione ciało tęgiego mężczyzny. Ale według Kriwickiego do odnalezienia zwłok nieznanego krępego mężczyzny w wieku około 40 lat, podziurawionych od kul, porzuconych w pewnej odległości od drogi, doszło już 4 września 1937 roku nocą: pięć pocisków przebiło głowę, siedem - ciało.

Przybyli na miejsce zdarzenia żandarmi doliczyli się dwunastu ran postrzałowych, a więc - potencjalnie - w ciele denata mogło tkwić dwanaście pocisków: zabójcy strzelali w okolice klatki piersiowej i okolice mózgoczaszki. Liczba pocisków oraz ich lokalizacja nie są, o czym jestem przekonany, przypadkowe. Strzałami do człowieka w środek czoła - strzał zasadniczy - oraz w jedną ze skroni - dla pewności, gdyby pierwszy strzał nie okazał się śmiertelny - podpisywali się przede wszystkim zabójcy wywodzący się ze służb specjalnych, nie tylko zresztą bolszewickich. Tak zginął na przykład Siergiej Jesienin (1895-1925), do którego stalinowscy agenci strzelali dwukrotnie z nagana ${ }^{62}$. Podobnie zginął Grigorij Rasputin, do którego mierzył w czoło i wystrzelił agent służb brytyjskich. Z punktu widzenia psychopatologii zabójców, taki zespołowy mord skutecznie wiąże jego uczestników, stanowiąc nie tylko jednoznaczne ostrzeżenie dla każdego, kto chciałby się wyrwać z kryminalnego układu, lecz także

\footnotetext{
60 В. Кривицкий. Я был агентом Сталина... Kriwicki miał na myśli następującą książkę: V. Serge, M. Wullens, A. Rosner. L'assassinat d'Ignace Reiss. Paris: Editions Pierre Tisné, 1938. Przypis - G. O. 61 Tamże, s. 266.

62 Zob. G. Ojcewicz, R. Włodarczyk, D. Zajdel. Zabójstwo Sergiusza Jesienina. Studium kryminalistyczno-historycznoliterackie. Szczytno: Wydawnictwo Wyższej Szkoły Policji, 2009.
} 
stanowi dowód w postaci zeznań przed przełożonymi z wykonanego brudnego zadania.

Sprawę zabójstwa „nieznajomego z Chamblandes” przydzielono pułkownikowi Robertowi Jacquiardowi, który kierował służbą bezpieczeństwa w danym kantonie. Niewykluczone, że Jacquiard szybko zdał sobie sprawę nie tylko ze złożoności samych czynności dochodzeniowo-śledczych, ale także z międzynarodowego charakteru zdarzenia, i jeśli uwzględniał udział w nim służb specjalnych, to śledztwo nie mogło toczyć się wedle działań rutynowych. Wkrótce po odnalezieniu zwłok na policję dotarł list, w którym życzliwy i zorientowany w sprawie nadawca donosił, iż zabity mężczyzna jest międzynarodowym aferzystą i zajmował się nielegalnym handlem bronią i że padł on ofiarą wewnętrznych porachunków. Z punktu widzenia historii zgadzało się w tym liście tylko jedno: Reiss rzeczywiście zginął w wyniku wewnętrznych działań agenturalnych. List o takiej samej treści trafił również do policji francuskiej, zapewne w Paryżu, z tą jednak różnicą, że piszący ten list wymienił nazwisko Eberharda. Stąd prosty wniosek, że nie był on obcy zabójcom.

Okoliczności na miejscu zdarzenia przemawiały za tym, że ofiara nie zginęła w Pully, lecz że została tutaj przywieziona i porzucona, o czym najdobitniej świadczyły ślady wleczenia denata po ziemi. Biorąc pod uwagę ciężar ciała Reissa, zwłoki musiało wlec co najmniej dwóch silnych osobników. Ponadto nikt z mieszkańców wspomnianego miasteczka nie słyszał strzałów. To jednak nie jest, w mojej ocenie, żadnym istotnym dowodem w sprawie, ponieważ stosowanie tłumików montowanych na broni palnej w sposób absolutnie satysfakcjonujący zmniejsza hałas, jaki towarzyszy wystrzałowi. Poza tym nie wiadomo, czy przesłuchano wszystkich mieszkańców Pully i czy przypadkiem nie woleli oni milczeć niż z uwagi na potencjalne zagrożenie własne okazać wylewność, składając zeznania przed żandarmami.

W wyniku przeszukania zwłok żandarmi odkryli, że zmarły miał przy sobie czechosłowacki paszport na nazwisko „Hermann Eberhardt”63, z którego wynikało, że był urodzony 1 marca 1889 roku w Czechach $^{64}$, portfel z pokaźną sumą pieniędzy (co wykluczało wersję napadu rabunkowego) oraz bilet na pociąg do Reims, miasta położonego w północno-wschodniej części Francji w odległości ok. 160 km od Paryża; tam po raz pierwszy Reiss miał się spotkać z Lwem Siedowem. Na dworcu w Reims czekała zapasowa grupa egzekucyjna zorganizowana przez Spiegelglasa na wypadek, gdyby w Lozannie nie udało się zlikwidować radzieckiego szpiega.

Bilet do Reims był przebity pociskiem rewolwerowym (zapewne od nagana, ulubionej broni zabójców NKWD), lecz na bilecie widniały już inne dane personalne niejakiego Steffa Brandta. Zwykle bilety i inne ważne dokumenty ludzie praworęczni

63 We wspomnieniach Waltera Kriwickiego występuje nie imię „Hermann”, lecz „Hans” (Ганс) Eberhardt. Zob.: В. Кривицкий. Я был агентом Сталина..., s. 257.

64 Na marginesie pewna ciekawostka: Natan Porecki urodził się, jak pisałem, 1 stycznia 1889 roku, czyli w Nowy Rok, i być może na upamiętnienie tej chwili otrzymał imię „Natan”, co znaczy „podarunek, prezent”. W fałszywym czechosłowackim paszporcie zachowano rok urodzenia Poreckiego i dzień, w którym przyszedł na świat, tj. pierwszego dnia miesiąca, ale zmieniono styczeń na marzec, uwiarygodniając $\mathrm{w}$ ten sposób w wysokim stopniu dane o dacie urodzenia okaziciela dokumentu $\mathrm{z}$ jego wyglądem zewnętrznym. 
przechowują w wewnętrznej górnej lewej kieszeni ubrania. Tak mogło być i w przypadku Reissa, a ślad na bilecie po postrzale świadczy, że rana objęła okolice serca. Wskazówki na zegarku zabitego zatrzymały się i wskazywały godzinę 9:40, w ręce zaś Reiss ściskał pęk siwych żeńskich włosów. Autorka nie uściśla, w której ręce denat trzymał żeńskie włosy i czy były to włosy naturalne lub sztuczne, a dla śledztwa takie szczegóły są przecież istotne. Do chwili ustalenia tożsamości Reissa mówiono o nim jako o „nieznajomym z Chamblandes”.

Ciekawe, w jaki sposób policja Szwajcarii zdołała ustalić, do kogo należą siwe włosy, które były w ręce denata, skoro Schildbach i zabójcy pośpiesznie opuścili ten kraj? Zapewne „identyfikacji” kryminalistycznej właścicielki włosów dokonano na podstawie zeznań Poreckiej i Steiner. Steiner wiedziała przecież, komu wynajęła auto i widziała, jak wyglądali jej znajomi. Porecka zaś feralnego dnia spotkała się z Schildbach i na pewno zwróciła uwagę na kolor jej włosów oraz uczesanie. Czy takich dowodów z zeznań dwóch świadków nie dałoby się dzisiaj z powodzeniem podważyć w postępowaniu procesowym przed sądem? Gertruda Schildbach w 1937 roku liczyła 41 lat, nie jest to więc wiek, w którym kobiety na ogół znacznie siwieją. Występowanie siwych włosów wskazuje nie tylko na aspekty czysto fizjologiczne organizmu agentki, lecz także na obecność najprawdopodobniej wielu sytuacji stresowych w jej życiu, które również sprzyjają pogłębianiu się procesu siwienia.

Jak wspomniałem, natychmiast po akcji Gertruda Schildbach i młodszy od niej o osiem lat kochanek, opuścili Szwajcarię, porzucając przed stacją kolejową w Genewie auto ze śladami krwi w kabinie. Ta właśnie dość niecodzienna okoliczność zastanowiła 5 września 1937 roku tamtejszą żandarmerię, która zainteresowała się danym pojazdem. Zastawiono pułapkę, a gdy 6 września 1937 roku do zaparkowanego samochodu podeszła Renata Steiner, zatrzymano ją i poproszono o złożenie zeznań. W ich trakcie wyjaśniło się, że Steiner wynajęła samochód znajomym, nie pytając i nie wiedząc, do jakich celów będzie im służyć. Policji szwajcarskiej nie udało się udowodnić Renacie Steiner współudziału w zabójstwie Reissa.

Wkrótce, bo już 6 września 1937 roku, na policję w Lozannie zgłosiła się Jelizawieta Porecka, która dowiedziała się z gazet, że nocą 4 IX 1937 na drodze z Lozanny do Pully znaleziono zwłoki mężczyzny mającego przy sobie czechosłowacki paszport na nazwisko Hansa Eberharda. Kobieta była przekonana, że chodzi o jej męża Ignacego Reissa. Dodała, że Reiss został najprawdopodobniej zabity przez czekistów za zerwanie $\mathrm{z}$ radzieckimi służbami specjalnymi.

W trakcie śledztwa policja szwajcarska współpracowała z policją francuską. W sprawozdaniu na temat śledztwa w sprawie zabójstwa Reissa, datowanym na 2 stycznia 1938 roku, Jacquiard nie ukrywał swojej irytacji z powodu powściągliwości kolegów z Francji i ich działania na przekór szwajcarskiemu pułkownikowi. Na przykład francuska policja kryminalna dwukrotnie zatrzymywała Marinę Cwietajewą i przesłuchiwała ją przez wiele godzin. Cwietajewa twierdziła, że niczego nie wiedziała o działalności męża. Rosyjska emigrantka, Zinaida Szachowska ${ }^{65}$, napisała w swoich

65 Księżna Zinaida Szachowska, po mężu Malewska-Malewicz (1906-2001) - rosyjska poetka, prozaik, krytyk literacki, dziennikarka. Na emigracji od 1920 roku. W Paryżu od 1925. Autorka interesującej memuarystyki, w której głównymi bohaterami są wybitne postaci rosyjskiego świata kultury, 
wspomnieniach, że Cwietajewa, poznawszy dowody udziału jej męża w zabójstwie Reissa, miała tak odpowiedzieć: „Jego zaufanie mogło zostać nadużyte, moje zaufanie do niego jest niezachwianie"66. Po tym oświadczeniu władze francuskie odstąpiły od oskarżenia jej o współsprawstwo.

Z kolei 9 listopada 1937 roku Jacquiard, zgodnie zresztą ze stanem faktycznym, zakomunikował, że w sprawę jest zamieszany agent NKWD, Siergiej Efron, ale, jak wiadomo z historii, władze francuskie nie podjęły żadnych czynności mających na celu zatrzymanie podejrzanego w kraju i dlatego można zasadnie przyjąć, że nagły wyjazd Efrona z Francji nastąpił w porozumieniu francuskich służb specjalnych z radzieckim wywiadem. Nie jest przecież odkrywcze stwierdzenie, że międzynarodowe służby specjalne w określonych zakresach ze sobą współpracują, a podejmowane przez nie decyzje zawsze stanowią perfekcyjny rachunek strat i zysków, jakie można ponieść lub osiągnąć, decydując się na pewne kroki w odniesieniu do konkretnych osób. Przypadek nagłego wyjazdu Efrona nie jest przecież odosobniony: razem z nim w trybie pilnym opuszczą Francję inni współpracownicy NKWD, bezpośrednio powiązani ze „Związkiem Powrotu do Ojczyzny” i zabójstwem Ignacego Reissa.

Pułkownik Jacquiard wnioskował także do władz francuskich o zbadanie działalności dwóch pracowników ambasady radzieckiej w Paryżu, małżeństwa Grozowskich Arnolda $^{67}$ i jego żony, Lidii. Arnold Grozowski, korzystając z przywileju dyplomatycznego, gdy zrobiło się niebezpiecznie w związku ze sprawą Reissa, pośpiesznie opuścił Francję, pozostawiając w niej swoją żonę, być może w roli „zakładnika” francuskich służb specjalnych. Gdy Szwajcarzy zwrócili się do Francuzów z wnioskiem o wydanie im Lidii Grozowskiej po przedstawieniu materiału prokuratorskiego, paryska policja, mimo presji radzieckich służb dyplomatycznych we Francji, najpierw przesłuchała Grozowską 15 grudnia 1937 roku, a dwa dni później aresztowała, natomiast sąd wypuścił warunkowo po uiszczeniu pokaźnej kaucji w wysokości 50000 franków i odebraniu zobowiązania o nieopuszczaniu kraju ${ }^{68}$. W rzeczy samej Grozowska skorzystała z okazji i potajemnie opuściła Francję. Wiedziała, że w danej sytuacji może być „bezpieczna" tylko pod skrzydłami protektorów, czyli moskiewskiego NKWD. Wiele zatem wskazywało na to, że rząd francuski nie chciał się narażać rządowi radzieckiemu i wolał zachować lepsze relacje z Kremlem niż z policją szwajcarską. W powieści Kłamstwo (Ложь) były generał Białej Armii, Piotr Krasnow (1869-1947), napisał: „Ignacy Reiss, nasz były agent, który odmówił powrotu do Związku, i który uciekł najpierw do Holandii, a potem do Szwajcarii, został zabity niedawno w Lozannie. Organizatorka tego

tej rangi, co Iwan Bunin czy Vladimir Nabokov. Zob. 3. А. Шаховская. Отражения: эссе, письма. Paris: YMCA-Press, 1975.

66 Л. Клот. Игнатий Рейсс...

67 Arnold Grozowski (1901-?) - agent sowieckich służb specjalnych. Od 1926 - współpracownik INO NKWD. Od 1927 - jako sekretarz radzieckiego konsulatu w Wyborgu zajmował się pracą wywiadowczą. W latach 30. pracował w Belgii i Francji pod przykryciem w roli przedstawiciela handlowego. Od 11 XII 1935 - starszy lejtnant bezpieczeństwa państwowego (odpowiednik wojskowy - stopień majora). Od VI 1938 - Komendant Wydziału Transportu Północno-Kolejowego Obozu Pracy. Dalsze jego losy nie są znane. Niewykluczone, że zginął w ramach stalinowskich czystek.

68 Kwotę tę, która pochodziła z kasy operacyjnej NKWD, wymienia Walter Kriwicki. Zob.: В. Кривицкий. Я был агентом Сталина..., s. 265. 
zabójstwa, nasz współpracownik, Lidia Grozowska, jest w pełni bezpieczna w Paryżu, w radzieckiej ambasadzie" 69 .

W wyniku przeprowadzonego przez pułkownika Roberta Jacquiarda śledztwa przed szwajcarskim sądem stanęła tylko Renata Steiner (1908-1986), urodzona w szwajcarskim Sankt Gallen, nauczycielka w Zurychu, członkini Komunistycznej Partii Szwajcarii. Przed zabójstwem Reissa dwukrotnie przebywała w Moskwie, gdyż, jak sama mówiła, „chciała zrozumieć rolę kobiet rosyjskich w życiu politycznym”70. W 1932 roku Steiner poznała się z osobami sympatyzującymi z komunistami. Dwa lata później wyjechała na sześć tygodni do Moskwy, jak podaje historyk Peter Huber (1954), autor książki Szwajcarscy komuniści w Moskwie: zdrajcy i niewolnicy Międzynarodówki Komunistycznej ${ }^{71}$. Do pracy w INO NKWD zwerbował ją Siergiej Efron. Związek Radziecki musiał szybko urzec tę młodą kobietę, ponieważ związała się ze stalinowskimi służbami specjalnymi, a liczne grono rosyjskich kochanków stanowiło doskonałe źródło informacji. Pracownicy NKWD podstawili jej nawet swojego agenta, niejakiego Molijenkę, za którego Steiner wyszła za mąż i który pozostał w ZSRR. Są dowody na to, że Steiner, aby uzyskać radziecki paszport i móc wyjechać do Moskwy, wykonywała różnorodne zadania na rzecz Kremla, śledziła także Reissa i wynajęła w Bernie auto dla zabójców radzieckiego agenta. Peter Huber napisał, że Renatę Steiner „zlikwidowano podczas jej kolejnego pobytu w Moskwie”72. Innego zdania jest Władimir Weichman, który napisał, że „Życie Renaty Steiner [po zabójstwie Reissa - G. O.] było długie, lecz jego szczegóły nie są znane prócz tego, że zmarła w 1986 roku"73.

Zwłoki Ignacego Reissa poddano kremacji. Z wypowiedzi Jelizawiety Poreckiej wiadomo, że dopiero pod koniec września, a więc po ponad trzech tygodniach od zabójstwa sowieckiego szpiega, została wezwana do kolumbarium w Lozannie, gdzie przekazano jej urnę, w której miały się znajdować prochy Natana Poreckiego. Nie wiadomo jednak, kto był zleceniodawcą kremacji i nie wiadomo, czy w przekazanej Poreckiej urnie rzeczywiście znajdowały się spopielone szczątki jej męża. To jeszcze jedna $\mathrm{z}$ wielu tajemnic, w których tak się lubowały nie tylko stalinowskie służby specjalne. Jedyny oficjalny nekrolog o śmierci Reissa ukazał się w antystalinowskim paryskim „Biuletynie Opozycji”. Rząd Nikity Chruszczowa (1894-1971) zrehabilitował Ignacego Reissa w 1960 roku.

W grudniowym numerze „Biuletynu Opozycji”, w artykule GPU zabija i za granica, Lew Siedow pisał: „ «Ojciec narodów» ze swoimi Jeżowowami zbyt dobrze wie, iluż potencjalnych Reissów jest we wszystkich aparatach. Lozańskie zabójstwo powinno im wszystkim - i nie tylko im - posłużyć jako ostrzeżenie... Dlatego z większą energią

69 П. Краснов. Ложь. Париж: Издательство В. П. Сияльского, 1939. [Online:] <https://books. google.pl/> (dostęp: 11.06.2017).

70 Л. Клот. Игнатий Рейсс...

71 Zob.: P. Huber. Stalins Schatten in der Schweiz. Schweizer Kommunisten in Moskau: Verteidiger und Gefangene der Komintern. Erich: Chronos Verlag, 1994.

72 Podaję za: Л. Клот. Игнатий Рейсс...

73 В. Вейхман. Каждыйдень я прихожуна пристань. [Online:] <https://proza.ru/2009/10/31/512> (dostęp: 31.05.2017). 
powinna prasa robotnicza i robotnicze organizacje demaskować stalinowskie przestępstwa. Tylko szerokie nagłośnienie przestępstwa może nałożyć kaganiec na wściekłego uzurpatora"74.

Zgon Reissa wywołał także poważniejsze reperkusje polityczno-organizacyjne: gdy sprawy wyszły na jaw, gdy stało się jasne, że zginął człowiek z rąk bolszewickich służb specjalnych, a więc - w powszechnym odczuciu - komunistów, znacznie się pogorszył stosunek Szwajcarów do „czerwonych”. W 1937 roku zabroniono oficjalnie działalności Komunistycznej Partii Szwajcarii w dwóch kantonach - Genewie i Neuchâtel, a 29 listopada 1940 roku zakaz objął już cały kraj. Na nic się zdały skargi członków KPS kierowane do sądu najwyższego, ponieważ sędziowie na ogół odmawiali ich rozpatrywania.

Można zasadnie zapytać: czy zorganizowanie agenturalnego zabójstwa Reissa wynikało wyłącznie $\mathrm{z}$ chęci Moskwy pokazowego ukarania zbuntowanego agenta? Niekoniecznie tylko z tej przyczyny. Jak podaje Rogowin, zaraz po egzekucji Reissa „agenci Jeżowa rozpoczęli polowanie na jego archiwum, które przechowywała wdowa. (...) Część notatek Reissa, odzwierciedlających kuchnię moskiewskich procesów, została opublikowana w grudniowym numerze „Biuletynu Opozycji” z 1937 roku”75. W związku z powyższym Walter Kriwicki wspominał:

Mniej więcej w połowie września pojawił się mój młody pomocnik Hans Bruss. Był roztrzęsiony, dowiedziawszy się o zabójstwie Reissa. Otrzymał instrukcje, by jechać do Holandii, gdzie przebywała wdowa Reissa. Dostał polecenie wykradzenia notatek i listów, które pozostawił Reiss, ale powrócił z pustymi rękoma. Zmusili go więc, aby jechał ponownie i nie cofał się przed niczym, nawet przed zabójstwem, by tylko wykraść papiery. Zrozpaczony, ze łzami w oczach, przyjechał do mnie po radę. Powiedziałem mu, że Reiss był idealistą, prawdziwym komunistą i że przyszła historia ruchu rewolucyjnego i robotniczego osądzi zabójców z OGPU. Poradziłem mu, by sabotował niebezpieczne zadanie, które otrzymał od Spiegelglasa, i powiedziałem, jak to ma zrobić"76.

Z tego by wynikało, że Reiss mógł dysponować pisemną wiedzą o czymś, co najprawdopodobniej mocno kompromitowałoby Kreml, gdyby wyszło na jaw, i dlatego $\mathrm{z}$ takim enkawudeowskim zapałem ludzie Jeżowa starali się do interesujących ich materiałów dotrzeć. Rosyjski historyk, archiwista i działacz praw człowieka, Nikita Pietrow $(1957)^{77}$, zakłada, że przyczyna tak gwałtownej nagonki na Reissa, w której wyniku zginął, miała podtekst przede wszystkim polityczny, albowiem radziecki szpieg był dobrze zorientowany w tajnych rozmowach, jakie prowadził Hitler/Ribbentrop ze Stalinem/Mołotowem. Prawdą jest, o czym pisze także Rogowin, że w latach 30. XX w. zarówno Wiktor Kriwicki, jak i Ignacy Reiss zajmowali się zbieraniem informacji o wojskowych przygotowaniach Hitlera do wojny. Według Pietrowa, „na posiedzeniu

74 «Бюллетень оппозиции» 1937, nr 58-59, s. 22.

75 В. 3. Роговин. Прозрение и гибель..., s. 683-684).

76 В. Кривицкий. Я был агентом Сталина..., s. 266.

77 Dr Nikita Pietrow to znany w Rosji autor książek o KGB i represjach systemu totalitarnego. Wiele lat pracował w archiwach Łubianki. Jest zastępcą przewodniczącego rady Naukowo-Informacyjnego i Oświatowego Centrum „Memoriał”. Odznaczony 24 marca 2005 roku przez Prezydenta RP Aleksandra Kwaśniewskiego Krzyżem Kawalerskim Orderu Zasługi Rzeczypospolitej Polskiej za wybitne zasługi w ujawnieniu i udokumentowaniu prawdy o represjach wobec ludności polskiej w ZSRR. 
Biura Politycznego Stalin zapytał Litwinowa, czy obcokrajowcy wiedzą o tych rozmowach. Naciskał, aby zapobiec jakiemukolwiek wyciekowi informacji. Dowiedziawszy się, że materiały dotyczące rozmów miał Reiss, Stalin krzyczał do Jeżowa: «Niech go Pan zlikwiduje, albo ja zlikwiduję tego, kto nie wykona moich poleceń!». W tej sytuacji Reiss nie mógł przeżyć"78.

Gdy tylko sprawa zabójstwa Reissa wyszła na jaw, Siergiej Efron i Nikołaj Klepinin zostali przerzuceni najpierw do Hiszpanii, następnie do ZSRR, gdzie od paru miesięcy przebywała już Ariadna Efron (1912-1975). „O życiu Nikołaja Klepinina, starszego brata ojca Dmitrija, wiadomo dość wiele. Oficer Białej Armii, członek Rosyjskiego Studenckiego Ruchu Chrześcijańskiego, w Paryżu współpracował z YMCA-Press; w 1928 roku pracuje już w gazecie „Eurazja”, założonej przez Siergieja Efrona. Przyjaźnił się z Mariną Cwietajewą i, począwszy od praskich lat, stale wynajmowali mieszkania obok siebie" - napisała Ksenia Kriwoszeina ${ }^{79}$. Uciekinierzy zamieszkali w listopadzie 1938 roku na daczy w Bołszewie pod Moskwą, przy ulicy „Nowy Byt” 4/33 (obecnie ul. Jakowa Swierdłowa 15). Efron nazywał się teraz Andriejew, a Klepininowie nosili nazwisko „Lwow”. Klepinin znów działał pod przykryciem, pracując oficjalnie we Wszechzwiązkowym Towarzystwie Związków Kulturowych z Zagranicą. Potem dołączyli do nich pozostali członkowie rodzin: Antonina Klepinina z dwoma synami, Aleksiejem i Dmitrijem Sezemanami, a w czerwcu 1939 - Marina Cwietajewa (1892-1941) z synem Gieorgijem (1925-1944). Po dwóch miesiącach od jej przyjazdu zaczęły się aresztowania.

Chronologia tragicznych wydarzeń 1939 roku zaczyna się od Ariadny Efron, którą NKWD uwięziło 27 sierpnia 1939 roku. Z kolei 10 października został aresztowany Siergiej Efron, a nocą, z 6 na 7 listopada, na Łubiankę trafili Nina i Nikołaj Klepininowie oraz Aleksiej Sezeman. Dnia 28 lipca 1941 roku w przejściowym więzieniu orłowskim Klepininowie i Efron zostali osądzeni jako francuscy szpiedzy i skazani na "grupowe rozstrzelanie"; wyrok wykonano: Klepininowie byli rozstrzelani 27 sierpnia 1941 roku $^{80}$, a Efron - 16 października 1941.

O Ariadnie Efron Ksenia Kriwoszeina napisała:

W połowie lat 30. dzięki kontaktom ojca udaje się ją zatrudnić w czasopiśmie „Nasz Związek” („Наш Союз”), będącym w rzeczy samej głosem paryskiego „Związku Powrotu do Ojczyzny”. Jakkolwiek byłaby naiwna, lecz niespodziewanie zjawiające się $\mathrm{w}$ rodzinie pieniądze, tajemnicze zniknięcia ojca, który mówił, że jedzie w „delegację”, nie mogły nie wywoływać ciekawości córki: czymże zajmuje się ojciec? A ojciec zajmował się werbunkiem emigrantów i otrzymywał pieniądze z Moskwy za aktywną pracę werbownika. Według niektórych danych, udało się mu zwerbować około 24 osób $^{81}$.

A sama Ariadna Efron, gdy została zrehabilitowana (1955), w piśmie do prokuratury wojskowej, tak pisała o swoim ojcu, pragnąc, aby on także doczekał się zwrotu

\footnotetext{
78 Великие операции спецслужб...

79 К. Кривошеина. Неэвклидов палиндром...

80 Według innych źródeł: 30 VII 1941.

81 Wadim Rogowin pisze, że w czasie przesłuchań na Łubiance Siergiej Efron wymienił nazwiska około 30 agentów, których zwerbował na rzecz sowieckiej agentury. Zob.: В. З. Роговин. Прозрение и гибель Игнатия Райса..., s. 682.
} 
dobrego imienia i oczyszczenia z zarzutów, które doprowadziły go do śmierci: „Ojciec, w przeszłości biały emigrant, który później odkupił swoje błędy, swoją winę wobec Ojczyzny, uczynił wszystko, by je zmazać. Przez długie lata zajmował się pracą wywiadowczą za granicą, zorganizowawszy silną grupę wywiadowców" ${ }^{\text {82 }}$. A w innym wniosku dotyczącym rehabilitacji Siergieja Efrona wspomniała o „zadaniu, które grupie kierowanej przez mojego ojca, przydzielił Spiegelglas" ${ }^{\prime 3}$. Z kolei w notatce związanej z procedurą rehabilitacyjną, którą na temat Efrona przygotował zarząd śledczy KGB, wskazywano, że „W ciągu wielu lat Efron był wykorzystywany jako szef grupy i aktywny werbownik, z jego udziałem przez organy NKWD zostało zwerbowanych wielu białych emigrantów (...) W Związku Radzieckim Efron przebywał pod nazwiskiem "Andriejew» i był na utrzymaniu organów NKWD"84.

We wspomnieniach Dmitrija Sezemana zajdujemy fragment, w którym wskazuje on na Efrona jako bezpośredniego zabójcę Reissa, lecz zgadza się z autorem wywia$\mathrm{du}$, że tego nie udowodniono. Pisze ponadto o tym, czego był naocznym świadkiem jako nastolatek, a co świadczy o załamaniu nerwowym, jakie przeżywał mąż Mariny Cwietajewej:

Moja mama [Nina Klepinina - G. O.] bardzo szybko, według mnie, zrozumiała, że to wszystko źle się skończy i była w jakiejś depresji. A Siergiej Jakowlewicz [Efron - G. O.] w jeszcze większej. Przesiadywał w zamknięciu przez cały dzień w swoim pokoju. I pewnego razu, nagle słyszę przez drzwi z tamtej połowy [domu - G. O.] głośny szloch. Moja mama była w domu, rzuciła się w tamtym kierunku i, jak to rozumiem, przez długi czas go pocieszała. A kiedy wróciła, zapytałem: „Co się dzieje?”. Ona na to: „Nic, po prostu Sierioża źle się czuje” ${ }^{\text {”. }}$.

Czy Siergiej Efron miał powody, by się źle czuć? Zdecydowanie tak, o czym przesądziła jego agenturalna przeszłość. Tak pisano o niej w Cieniach zamku Arsin:

Tak, to on werbował drobne płotki w środowisku emigracyjnym jako materiał rozchodowy NKWD. Tak, to on uczestniczył w porwaniu archiwum Lwa Trockiego i kierował śledzeniem jego syna. Tak, to on wchodził w skład grupy kuratorów śledzenia i zabójstw niezgadzających się z polityką Stalina komunistów. Ale to także był on - Siergiej Efron, który uratował życie generałowi Denikinowi, uprzedziwszy go o przygotowywanym na niego porwaniu. (...) Od 1934 roku Efron jest już „na posadzie i z pensją”, wykonuje polecenia swoich kuratorów. Zajmował się przede wszystkim werbunkiem małych pionków, organizacją śledzenia, pomagał w wysłaniu wolontariuszy na hiszpańską wojnę domową, wstąpił na polecenie NKWD do loży masońskiej i donosił wedle reguł reżimu, agitując do powrotu do ZSRR tych, którzy nie byli w stanie odnaleźć się na emigracji. Taki oto był schemat werbunku: „Chcesz wrócić? Na prawo do powrotu trzeba u nowej władzy zasłużyć.... Wartości szczególnej Efron jak agent nie przedstawiał i był u nowych gospodarzy niczym popychadło, póki się nie wybił. ${ }^{86}$

\footnotetext{
82 В. З. Роговин. Прозрение и гибель Игнатия Райса..., s. 682.

83 Tamże.

84 В. 3. Роговин. Прозрение и гибель Игнатия Райса..., s. 683.

85 М. Соколов. Дмитрий Сеземан: Марина Цветаева, Георгий Эфрон и возвращение в СССР. Чacms 2. [Online:] <https://www.svoboda.org/a/262899.html> (dostęp: 17.06.2017).

86 Тени замка Арсин. [Online:] <http://www.travel-journal.ru/phenomenons/2/576/> (dostęp: 6.06.2017).
} 


\section{Zakończenie}

W słusznej ocenie Ludmiły Kłot, „śmierć Ignacego Reissa stała się nie tylko przykładem skutecznej pracy stalinowskich służb specjalnych, ale także częścią historii kantonu Vaud ${ }^{87}$. W 75. rocznicę przypomniała sobie o niej gazeta «24 Heures», opublikowawszy artykuł pod nazwą Brudny cios GPU ${ }^{88}$ i przedstawiwszy najistotniejsze etapy śledztwa oraz sylwetki uczestników - organizatorów oraz zabójców - zamachu na życie wybitnego radzieckiego szpiega. O randze ówczesnego wydarzenia świadczą co najmniej trzy charakterystyczne fakty: po pierwsze, z danych sondażu, jaki przeprowadziło czasopismo „Illustré” oraz szwajcarska telewizja TSR, wynika, że zabójstwo Reissa znalazło się na liście stu najważniejszych historycznych wydarzeń tego państwa, do jakich doszło w XX wieku ${ }^{89}$, po drugie, bezkompromisowa postawa Reissa stała się inspiracją dla francuskiego producenta filmowego i scenarzysty Daniela Künzi (1958), który w 1995 roku nakręcił 53-minutowy film dokumentalny zatytułowany Ignacy Reiss, życie i śmierć rewolucjonisty ${ }^{90}$, wreszcie po trzecie, pomimo upływu lat nie słabnie zainteresowanie pisarzy postacią sowieckiego agenta, za czym przemawiają chociażby książki Eberharda Raetza z 2006 roku o ostatnim dniu wywiadowcy Reissa ${ }^{91}$ czy proza Władimira Weichmana (1934) Każdego dnia przychodzę nad przystańn ${ }^{92}$.

Z dokonanej prezentacji materiału związanego z pracą zagranicznej agentury stalinowskiej, w związku z zabójstwem Ignacego Reissa, płynie kilka zasadniczych wniosków:

1. Ignacy Reiss zginął z rąk agentów NKWD, ich grono oraz nazwiska są znane, lecz nie ma pewności, że są to wszystkie nazwiska i że są to rzeczywiste nazwiska agentów-likwidatorów.

2. Wedle dzisiejszej wiedzy krąg osób najściślej związanych ze sprawą Ignacego Reissa $\mathrm{z}$ podziałem na funkcje wygląda następująco:

a) Siergiej Spiegelglas - pełnomocnik Nikołaja Jeżowa i kierownik zadania oraz agenci spoza „Związku Powrotu do Ojczyzny”, jak: Rol(l)and Abbiate, Borys Afanasjew, Wadim Kondratjew, Lidia Grozowska, Arnold Grozowski, Dmitrij Smirenski;

b) Siergiej Efron - kierownik grupy operacyjnej, dysponujący agentami pracującymi pod przykryciem w "Związku Powrotu do Ojczyzny”, jak: Renata

87 Kanton Vaud ze stolicą w Lozannie jest położony w zachodniej części Szwajcarii.

88 Л. Клот. Игнатий Рейсс...

89 Zob.: Л. Клот. Знакомые тица: романдиы века на наших страницах | Le général Guisan élu Romand du siècle. [Online:] <http://nashagazeta.ch/news/12648> (dostęp: 1.06.2017).

90 Ignace Reiss, vie et mort d'un révolutionnaire, 53 minutes, TVSR, TVSI, Planète. W filmie tym fragmenty książki Elisabeth K. Poretsky, Our Own People ... czyta brytyjska aktorka i laureatka Oscara, Vanessa Redgrave (1937). Film Daniela Künzi otrzymał nagrodę na festiwalu filmowym Inter Svet na Ukrainie (Primé par le DIP à Genève et par le Festival international SVET en Ukraine).

91 Zob. także: E. Raetz. Hôtel de la Paix. Ein politischer Mord in Lausanne. Bretten: INFO Verlag, 2006.

92 В. Вейхман. Каждыйденья прихожуна пристань. [Online:] <https://proza.ru/2009/10/31/512> (dostęp: 31.05.2017). 
Steiner, Wiera Guczkowa-Traill, Nikołaj Klepinin, Antonina Klepinin, Piotr Schwarzenberg;

c) zabójcy: Rol(l)and Abbiate, Borys Afanasjew, Wadim Kondratjew, Dmitrij Smirenski i Gertruda Schildbach ${ }^{93}$.

Zachowanie Ignacego Reissa, polegające na zerwaniu z radzieckimi służbami specjalnymi, było działaniem świadomym, o czym świadczy nawiązanie przez niego wiosną 1937 roku kontaktów ze zwolennikami IV Międzynarodówki ${ }^{94}$ i uprzedzeniem o czekających ich wkrótce ze strony Moskwy represjach oraz nieodwołalnym zamiarze zlikwidowania zwolenników Trockiego za granicą oraz antystalinowskich komunistów.

Ignacy Reiss jako współpracownik NKWD wiedział, że za brak lojalności Kreml każe śmiercią, więc naiwne byłoby zakładanie, że został przez moskiewskich agentów zaskoczony. Likwidacja Reissa była tylko kwestią czasu. Odległość geograficzna nie stanowiła żadnej przeszkody, o czym najlepiej świadczy zabójstwo Lwa Trockiego, do jakiego na zlecenie Stalina doszło w 1940 roku w Meksyku.

Śmierć Ignacego Reissa potwierdza fakt istnienia wewnątrzorganizacyjnego zjawiska, które nazywam „kanibalizmem agenturalnym”, a polegającym na postępującym likwidowaniu agentów, którzy wcześniej sami wykonywali wyroki śmierci na wskazanych przez Moskwę do likwidacji osobach, przez kolejnych agentów wysłanych do przeprowadzenia działań operacyjnych ${ }^{95}$. W ten sposób „młodsi” zabójcy zabierali do grobu tajemnice swoich „starszych” likwidatorów. Zjawisko to potwierdza, że agentów służb specjalnych Stalin traktował instrumentalnie, nie wahając się skazywać na śmierć najbardziej mu oddanych, wręcz fanatycznych współpracowników, zajmujących nawet wysokie stanowiska ministerialne (np. kazus Nikołaja Jeżowa).

Najprawdopodobniej, gdyby nie list Ignacego Reissa do KC WKP(b), a ściślej jego opublikowanie przez francuskie media, w konsekwencji zaś nagłośnienie sprawy, wzmocnionej następnie przez zabójstwo radzieckiego agenta pod Lozanną, ten wybitny z punktu widzenia operacyjności NKWD agent podzieliłby zapewne los wielu innych szpiegów, o których wciąż milczy historia radzieckiego wywiadu. Ponieważ Reiss wybrał tę samą drogę głośnego trzaśnięcia drzwiami, jak inni wielcy szpiedzy - Walter Kriwicki czy Aleksander Barmin (1899-1987) ${ }^{96}$ - przedostał się do historii wywiadu agenturalnego i wciąż stanowi zagadkę, nad której rozwiązaniem nadal pracują badacze nie tylko w Rosji.

Do spopularyzowania sylwetki Ignacego Reissa przyczyniła się w dużej mierze jego żona, Jelizawieta Porecka, pisząc o swoim mężu wspomnienia i publikując je poza ZSRR.

93 O losach agenta Dmitrija Smirenskiego zob. np.: В. Вейхман. Каждый денъ...

94 Najczęściej wymienia się tutaj nazwisko lidera holenderskich trockistów, Hendricusa Sneevlieta (1883-1942).

95 Więcej o katach, wykonujących wyroki Stalina, czyli jego „psach”, zob. np: N. Pietrow. Psy Stalina. Tłum. J. Prus-Wojciechowska, K. Syska. Warszawa: Demart SA, 2012.

96 Aleksandr Barmin (właśc. Aleksandr Graff) - radziecki wywiadowca i dyplomata, który odmówił powrotu do ZSRR. Był mężem wnuczki prezydenta USA, Teodora Roosvelta, co w największym chyba stopniu przyczyniło się do tego, że nie zginął z rąk oprawców z NKWD. 
$\mathrm{Na}$ dzień dzisiejszy więcej argumentów przemawia za tym, że Siergiej Efron nie brał bezpośredniego udziału w zabójstwie Reissa, a więc - że do niego nie strzelał. Na skutek dekonspiracji siatki szpiegowskiej w Paryżu, którą kierował Efron, on sam i jego rodzina musieli pośpiesznie opuścić Francję. Wkrótce Efron oraz jego najbliżsi zostali poddani stalinowskim represjom w ramach wielkiego terroru. Efron został rozstrzelany przez NKWD, Marina Cwietajewa popełniła samobójstwo, Ariadna Efron trafiła na długie lata do więzienia, a 19-letni Gieorgij Efron zginął na Białorusi w sierpniu 1944 roku, zaledwie po dwóch miesiącach od pobytu na froncie II wojny światowej.

Dzięki wspomnieniom Dmitrija Sezemana, bezpośredniego świadka wydarzeń, w których bohaterem jest rodzina Siergieja Efrona oraz jego własna, tj. Nikołaja i Niny Klepininów, możemy z zaufaniem przyjąć nie tylko podawane przez Sezemana informacje o ludziach i sprawach, ale także zgodzić się wielokrotnie $z$ jego interpretacjami wydarzeń historycznych, w których uczestniczył on sam jako zaskoczone przez historię dziecko, młodzieniec i dorosły mężczyzna, jako mieszkaniec Francji i ZSRR.

Jest jeszcze jedna rzecz, która nie daje mi spokoju. Wiąże się ona z przebiegiem zdarzeń w dniu 4 września 1937 roku, ściślej - z akcją, w której użyto samochodu. Zarówno Kriwicki, jak i inni autorzy po nim i za nim powtarzają, że samochód pojawił się nagle i że wyskoczyło z niego kilku mężczyzn oraz że zwłoki Reissa z trudem zostały umieszczone w kabinie pojazdu. Kriwicki pisze: „Nagle zjawił się samochód i gwałtownie zahamował. Wyskoczyło z niego kilku mężczyzn, którzy napadli na Reissa. Reiss próbował się bronić. Z pomocą Schildbach, której pęk włosów pozostał w zaciśniętej dłoni zabitego, napastnikom udało się wepchnąć go do auta”. Wtóruje mu Mleczin: „Po obiedzie wyszli na spacer i wtedy na mało uczęszczanej drodze pojawił się samochód, z którego wyskoczyło kilku mężczyzn. Na siłę wepchnęli Poreckiego do auta, w którym go zastrzelili”.

Patrzę na fotografię auta, którą Ludmiła Kłot zamieściła w „Naszej Gazecie”, podpisując zdjęcie całkowicie jednoznacznie: „Samochód, w którym przewożono zwłoki Reissa”. Co prawda, mimo starań nie udało się mi jeszcze ustalić marki tego pojazdu, lecz sądzę, że wyglądem swoim przypomina najbardziej dwudrzwiowego chevroleta master de luxe z 1937 lub nieznacznie wcześniejszego roku - 1935 lub 1936. I tutaj moje wątpliwości się potęgują. Auto tego typu nie porusza się bezszelestnie, więc jeśli pojawiło się na głuchej drodze, musiało być już słyszane z pewnej odległości. Jeśli były włączone reflektory - także widziane. Ponieważ jest to dwudrzwiowy sedan, trudno mówić o kilku mężczyznach, którzy mieliby WYSKOCZYĆ z automobilu. Owszem, wyskoczenie jest możliwe, gdy auto jest czterodrzwiowe, lecz nie dwudrzwiowe, albowiem najpierw musiał wysiąść z samochodu kierowca i pasażer zajmujący przednie siedzenie (lub w odwrotnej kolejności), by mogli następnie wydostać się z auta pozostali pasażerowie. A zatem, jeśli Reiss usłyszał i dostrzegł nadjeżdżające z oddali auto, nie musiał w tym samym momencie uważać, że zbliża się do niego grupa likwidatorska, lecz gdy pojazd się zatrzymał, a z niego po kolei zaczęli pośpiesznie się wydostawać pasażerowie, jego podejrzenia musiały wziąć zapewne górę i dlatego zareagował natychmiast, przyciągając do siebie Schildbach - żywą tarczę. Dalej zdarzenia potoczyły się, być może, według scenariusza, który podałem.

I jeszcze jeden interesujący element, o którym nikt, jak dotąd, z badaczy nie napisał: moment umieszczania zakrwawionych zwłok Reissa w aucie: gdzie i jak je uloko- 
wano w automobilu? Na przednim czy na tylnym siedzeniu? Jeśli na tylnym, to w pozycji siedzącej pomiędzy dwoma zabójcami czy leżącej, a wtedy na zwłokach musieliby usiąść oprawcy. A jeśli z przodu, to kto podtrzymywał denata, by udawał śpiącego człowieka? I czy takie rozwiązanie nie było zbyt ryzykowne, bo wiązało się z szybkim zdemaskowaniem w przypadku zatrzymania pojazdu przez żandarmerię do kontroli? I czy wszyscy uczestnicy zdarzenia, a więc Reiss i pięciu agentów, razem sześć dorosłych osób, mogłoby się zmieścić w dwudrzwiowym sedanie? Z fotografii opublikowanej w „Naszej Gazecie” wynika, że bagażnik w danym pojeździe jest dosyć mały, więc wersja o upchnięciu zwłok krępego mężczyzny w tej części pojazdu jest raczej bardzo mało wiarygodna.

I jest jeszcze jedna wątpliwość: a może fotografia pojazdu, którą znalazłem w artykule Ludmiły Kłot, nie ma nic wspólnego ze sprawą Reissa? Może to tylko dziennikarska sztuczka? Jedynie Walter Kriwicki wspomina, że do akcji użyto auta produkcji AMERYKAŃSKIEJ. Owszem, marka Chevrolet spełniałaby to kryterium, ale nie zapominajmy, że czterodrzwiowe chevrolety sedany montowano w latach 1936-1939 w... Warszawie, a wtedy należałoby mówić o automobilu wyprodukowanym w przedwojennej Polsce. Zagadek jest zresztą więcej, lecz bez bezpośredniego dostępu do akt sprawy nie da się wielu z nich satysfakcjonująco rozwiązać.

Kapitan bezpieczeństwa państwowego ${ }^{97}$ Ignacy Reiss bez względu na to, jak będziemy go nazywać i postrzegać - jako bezkompromisowego i zaangażowanego ideowo żołnierza światowej rewolucji czy wytrawnego agenta radzieckich służb specjalnych - pozostaje osobą, o której nie można myśleć pozytywnie w kategoriach etycznych, ponieważ jego agenturalna przeszłość wymagała od bolszewickiego szpiega zachowań dwuznacznych, nie zawsze moralnie nienagannych, a do tego skrajnych, w tym - brania bezpośredniego lub pośredniego udziału w pozbawianiu ludzi życia, tych ludzi, których stalinowski system uznał za niepotrzebnych, niebezpiecznych, i dla niego niewygodnych. Winy Reissa związane z ciemną stroną pracy wywiadowczej nie są, jak uważam, w stanie wyrównać rachunków ludzkich krzywd. Ten stary bolszewik, przekonany, że Stalin prowadzi Rosję ku faszyzmowi i totalnej katastrofie, sam się stał tragiczną ofiarą reżimu, dla którego przez długie lata wiernie pracował. Ale nie wolno pomijać milczeniem chociażby tego ostatniego wołania sumienia, które doprowadziło do jawnego sprzeciwu wobec stalinizmu w obronie ludzkiej godności i wierności leninowskim ideałom - opublikowania demaskatorskiego listu do Komitetu Centralnego WKP(b). List ten był jednak opieczętowany kremlowskim piętnem śmierci, które zamykało kolejną sprawę, za którą stał największy z największych wrogów ludu - Stalin.

\section{Bibliografia}

Beevor A., Cooper A. Paryż wyzwolony. Tłum. J. Małecki. Kraków: Znak Horyzont, 2015.

Conquest R. Wielki Terror. Tłum. W. Jeżewski. Warszawa: Wydawnictwo Michał Urbański, 1997.

Duff W. E. A Time for Spies: Theodore Stepanovich Mally and The Era of The Great Illegals. Nashville and London: Vanderbilt University Press, 1999.

97 Temu stopniowi w NKWD odpowiadał wojskowy stopień pułkownika. 
Huber P. Stalins Schatten in der Schweiz. Schweizer Kommunisten in Moskau: Verteidiger und Gefangene der Komintern. Erich: Chronos Verlag, 1994.

ICL Decrees: No More „Reiss Factions”. [Online:] <http://www.internationalist.org/Reissfactions0301. html> (dostęp: 5.06.2017).

Ignace Reiss, vie et mort d’un révolutionnaire, 53 minutes, TVSR, TVSI, Planète.

Kuk A. Kanwa wywiadu agenturalnego. Tłum. G. Ojcewicz. Warszawa: Wydawnictwo Biura Kadr i Szkolenia Urzędu Ochrony Państwa, 1994.

Ojcewicz G., Włodarczyk R., Zajdel D. Zabójstwo Sergiusza Jesienina. Studium kryminalistyczno-historycznoliterackie. Szczytno: Wydawnictwo Wyższej Szkoły Policji, 2009.

Pietrow N. Psy Stalina. Tłum. J. Prus-Wojciechowska, K. Syska. Warszawa: Demart SA, 2012.

Poretsky E. K. Léon Trotsky, Les Nôtres: vie et mort d’un agent soviétique (Our own people). Tłum. Olivier Simon. Paris: Denoël, Les Lettres nouvelles, 1969.

Poretsky E. K. Our Own People: A Memoir of "Ignace Reiss" and His Friends. London: Oxford University Press, 1969.

Raetz E. Hôtel de la Paix. Ein politischer Mord in Lausanne. Bretten: INFO Verlag, 2006.

Reiss E. Ignace Reiss: In Memoriam. „New International” 1938, September, s. 276-278.

Scope of Sowiet Activity i United States. Hearing... 1956, 2 III.

Serge V., Wullens M., Rosmer A. L'assassinat d'Ignace Reiss. Paris: Editions Pierre Tisné, 1938.

Serge V., Wullens M., Rosner A. Lassassinat politique et l'U.R.S.S.; crime a Lausanne en marge des proces de Moscou (La mort d'Ignace Reiss). Paris: Pierre Tisné, 1938.

Sudopłatow P. Wspomnienia niewygodnego świadka. Tłum. J. Markowski. Warszawa: Dom Wydawniczy Bellona, 1999.

„Бюллетен оппозиции” [большевиков-ленинцев] 1937, № 58-59, сентябрь-октябрь.

„Бюллетен оппозиции” [большевиков-ленинцев] 1937, № 60-61, ноябрь-декабрь.

„Новое время” 1991, № 21, с. 36, 38.

„Новое время” 1993, № 4, с. 49.

„Последние новости” 1937, 24 октября.

„Столица” 1992, № 38, с. 56.

„Столица” 1992, № 39, с. 59-60.

Абрамов В. Евреи в КГБ. Палачи и жертвы. Москва: Яуза - Эксмо, 2005.

Антонов В. С., Карпов В. Н. Расстрелянная разведка. Москва: Международные отношения, 2008.

Архив Троикого. № 4921.

Бросса А. Агенты Москвы. „Иностранная литература” 1989, № 12.

Вейхман В. Каждый день я прихожу на пристань. [Online:] <https://proza.ru/2009/10/31/512> (dostęp: 31.05.2017).

Великие операции спецслужб. Между первой и второй мировыми войнами. Конфеты из ЛозанHol. [Online:] <http://greatoperation.narod.ru/3/konfloz.htm> (dostęp: 6.06.2017).

Военная литература. Мемуары. [Online:] <http://militera.lib.ru/memo/russian/poretskya_ek/01. html> (dostęp: 5.06.2017).

Залесский К. А. Империя Сталина. Биографический энциклопедический словарь. Москва: Вече, 2000.

Изменники и предатели. 1937. РЕЙСС Натан Маркович. [Online:] <http://www.fssb.su/historystate-security/history-state-security-traitors/80-1937-reyss-natan-markovich.html> (dostęp: 31.05.2017).

Каган Ю. М. Марина Цветаева в Москве. Путь к гибели. Москва: Отечество, 1992. 
Клот Л. Знакомые лица: романдиы века на наших страницах | Le général Guisan élu Romand du siècle. [Online:] <http://nashagazeta.ch/news/12648> (dostęp: 1.06.2017).

Клот Л. Игнатий Рейсс: загадочная смерть советского шпиона под Лозанной|Ignace Reiss, mort d’un espion soviétique à Lausanne. Online: <http://nashagazeta.ch/news/14121> (dostęp: 20.05.2017).

Краснов П. Ложь. Париж: Издательство В. П. Сияльского, 1939. [Online:] <https://books.google. $\mathrm{pl} />$ (dostęp: 11.06.2017).

Кривицкий В. Я был агентом Сталина. Записки советского разведчика. Москва: Терра-Terra, 1991. [Online:] <https://scepsis.net/library/print/id_559.html> (dostęp: 12.06.2017).

Кривошеина К. Неэвклидов палиндром имен и судеб, небесных и не очень. [Online:] <http://meremarie.com/life/neevklidov-palindrom-imen-i-sudeb/> (dostęp: 22.10.2016); „Новый журнал” 2016, № 10. [Online:] <http://newreviewinc.com/kseniya_krivosheina/> (dostęp: 18.10.2016).

Лесков В. Сталин и заговор Тухачевского. Москва: Вече, 2003. [Online:] <http://www.ereading.club/chapter.php/33771/47/Leskov_-_Stalin_i_zagovor_Tuhachevskogo.html> (dostęp: 11.06.2017).

Лосская В. Марина Цветаева в жизни (неизданные воспоминания современников). Москва: ПрозаиК, 1992.

Млечин Л. История внешней разведки. Карьеры и судьбы. Москва: ЗАО Центрполиграф, 2008.

Носик Б. Сент-Женевьев-де-Буа. Русский погост в предместье Парижа. [Online:] <https:// books.google.pl/books> (dostęp: 17.06.2017).

Порецкая Е. К. Наши. Воспоминания об Игнатии Райссе и его товарищах. Москва: Издательство ВДА, 1992. [Online:] <http://militera.lib.ru/memo/russian/poretskya_ek/index.html> (dostęp: 17.06.2017).

Прохоров Д. П., Лемехов О. И. Перебежчики. Заочно расстреляны. [Online:] <http://coollib. com/b/271956/read> (dostęp: 17.06.2017).

Прянишников Б. Незримая паутина: ОГПУ-НКВД против белой эмиграции. Москва: Яуза - Эксмо, 2004. [Online:] <https://unotices.com/book.php?id=178320\&page=96> (dostęp: 17.06.2017).

Роговин В. З. Прозрение и гибель Игнатия Райса. В: В. З. Роговин. 1937. Москва: [s.n.], 1996. [Online:] <http://www.litres.ru> (wersja PDF) (dostęp: 11.06.2017) .

Соколов М. Дмитрий Сеземан: Марина Цветаева, Георгий Эфрон и возвращение в СССР. Чacms 1. [Online:] <https://www.svoboda.org/a/262693.html>; Чacms 2. [Online:] <https:// www.svoboda.org/a/262899.html> (dostęp: 17.06.2017).

Тени замка Арсин. [Online:] <http://www.travel-journal.ru/phenomenons/2/576/> (dostęp: 6.06.2017).

Хубер П. Смерть в Лозанне. „Новое время” 1991, № 21.

Шаховская 3. А. Отражения: эссе, письма. Paris: YMCA-Press, 1975.

Энциклопедический словарь российских спецслужб. Автор-сост. А. Диенко, предисл. В. Величко. Москва: Русскій міръ, 2002.

\section{Internetowe źródła fotografii}

<http://blogrev.livejournal.com/1575359.html> (dostęp: 20.05.2017)

$<\mathrm{http}: / /$ mysteric.ru/mysteries/rollan-abbia-ot-agenta-do-rezidenta.html> (dostęp: 20.05.2017)

$<$ http://nashagazeta.ch/news/14121> (dostęp: 20.05.2017)

$<$ http://sea-writer.ucoz.ru/index/kazhdyj_den_prodolzhenie_3/0-362> (dostęp: 31.05.2017)

$<$ http://www.hrono.ru/slovo/2003_03/hly02.jpg> (dostęp: 20.05.2017)

$<$ http://www.travel-journal.ru/phenomenons/2/576/> (dostęp: 20.05.2017)

$<$ https://fr.pinterest.com/pin/376191375105313399/> (dostęp: 15.06.2017). 


\section{Aneks fotograficzny}

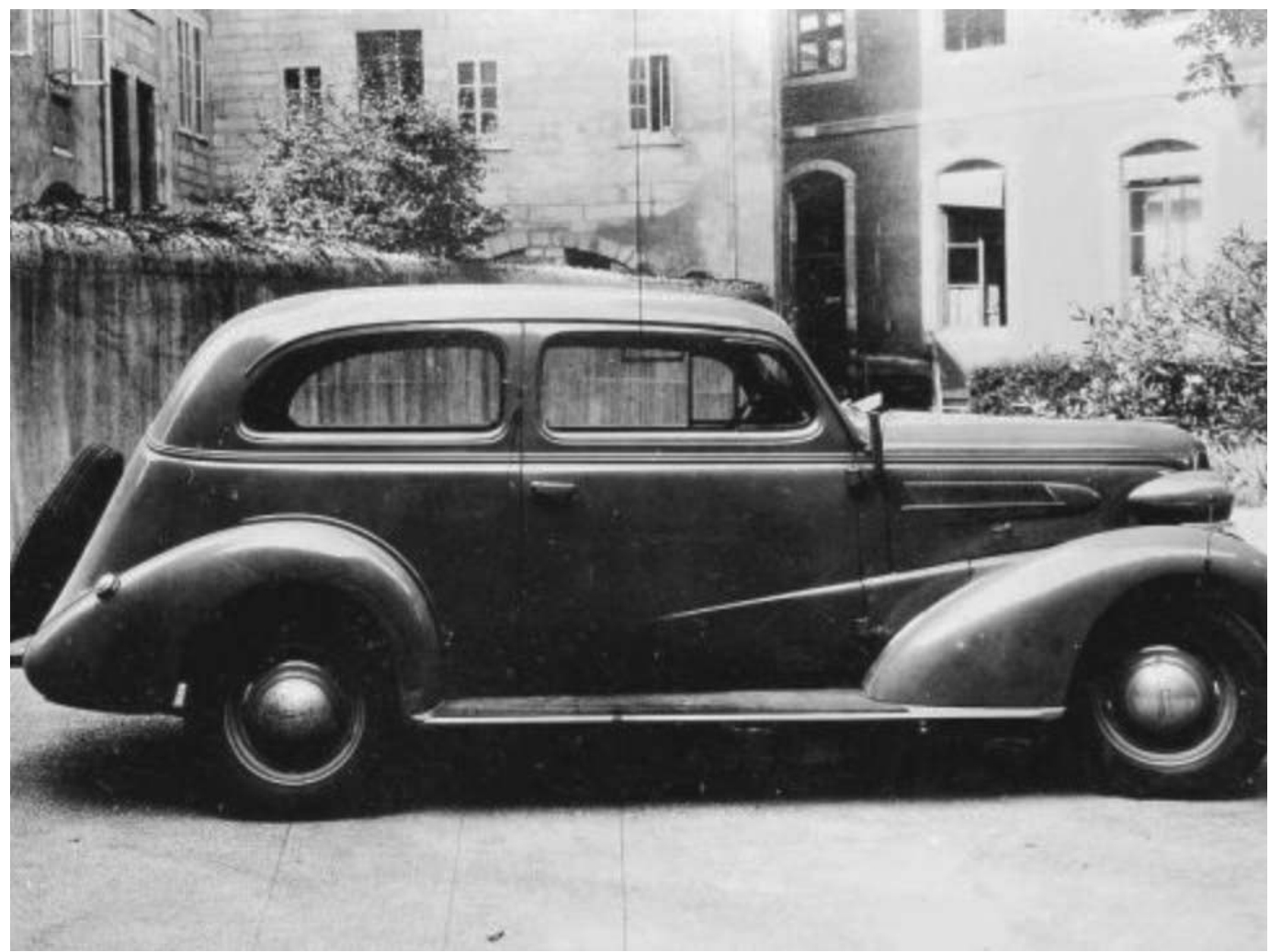

Fot. 1. Wynajęte przez Renatę Steiner auto, którym zabójcy przewieźli ciało martwego Ignacego Reissa i porzucili na drodze z Lozanny do Pully

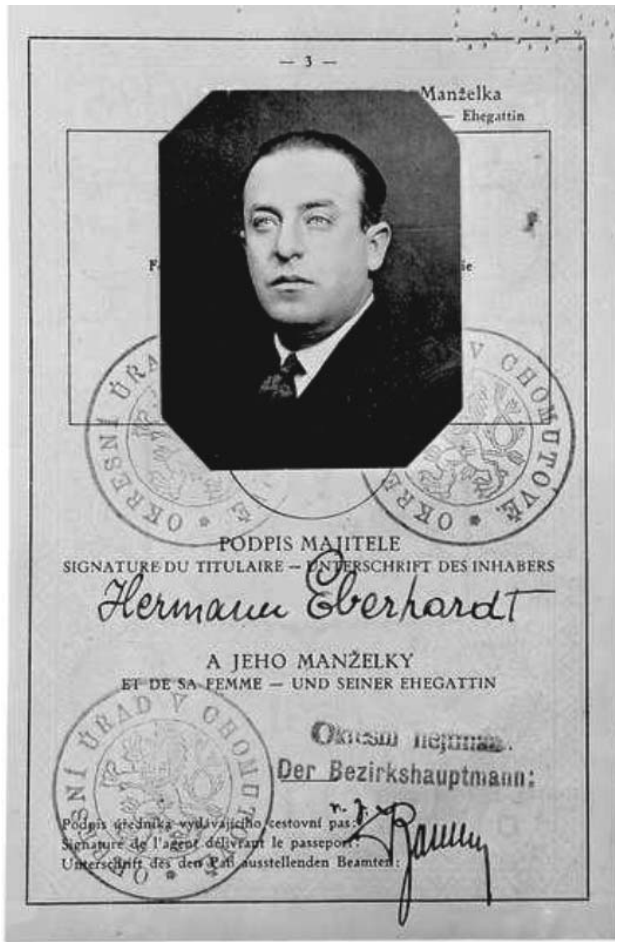

Fot. 2. Fałszywy czechosłowacki paszport, którym posługiwał się Ignacy Reiss jako Hermann Eberhardt 


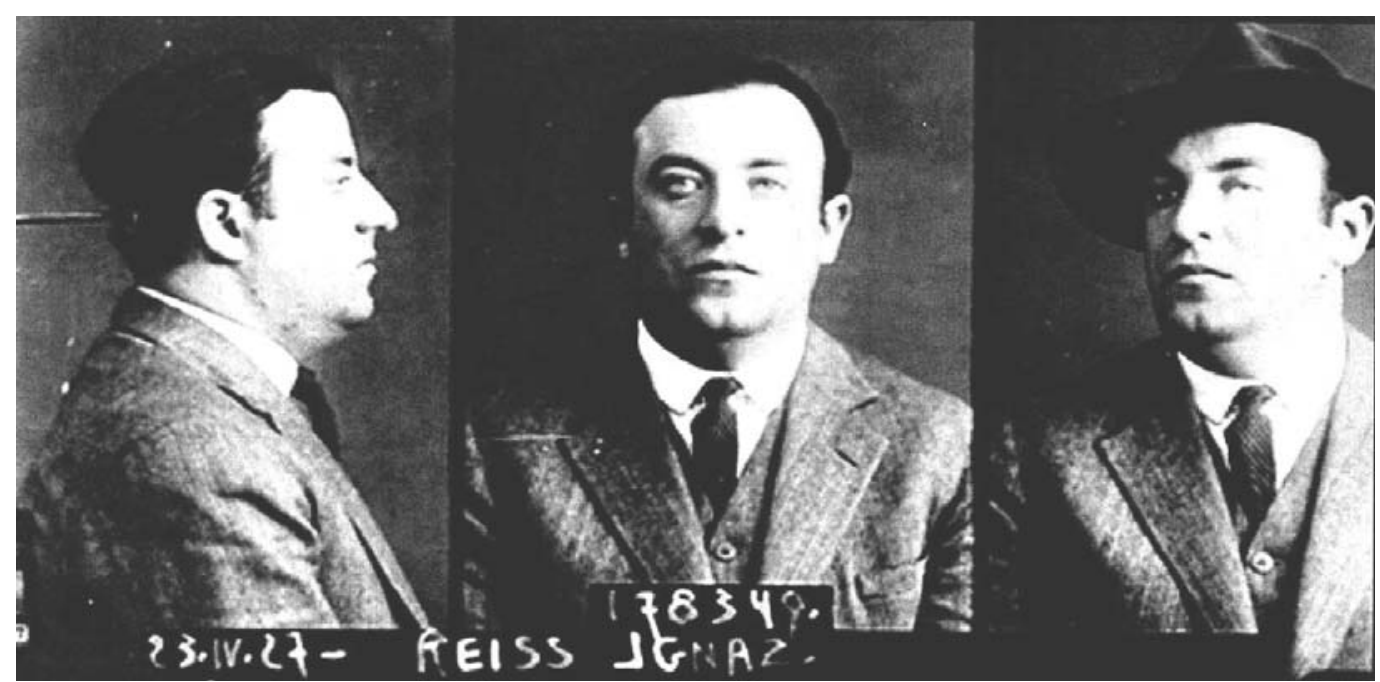

Fot. 3. Zdjęcia policyjne Ignacego Reissa wykonane w 1927 roku

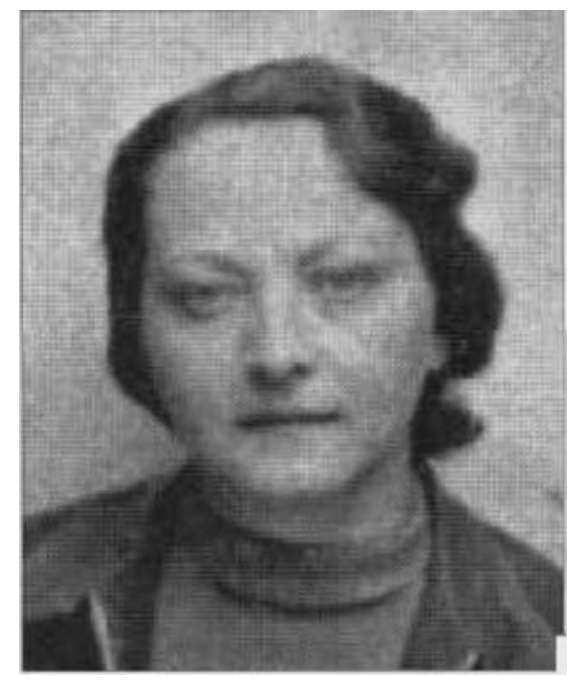

Fot. 4. Jelizawieta Porecka

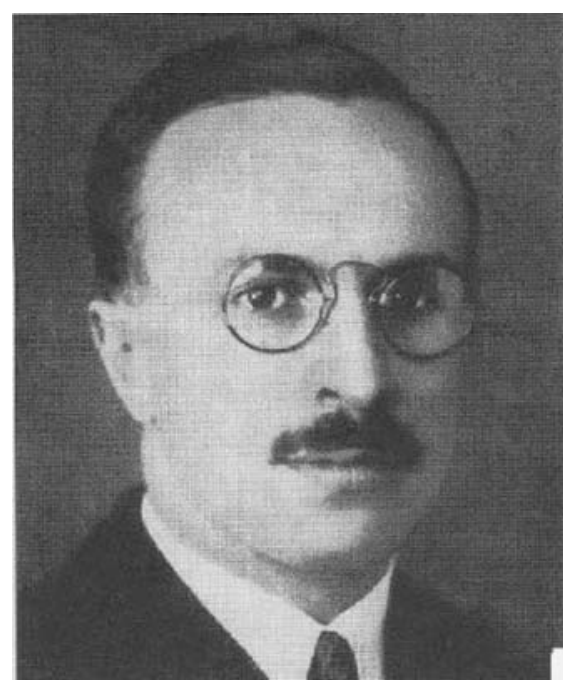

Fot. 6. Rol(l)and Abbiate (alias François Rossi i Władimir Prawdin)

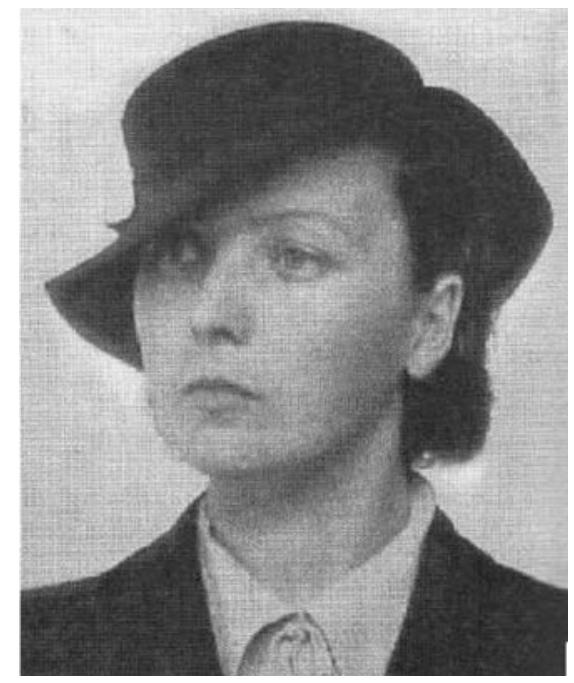

Fot. 5. Renata Steiner

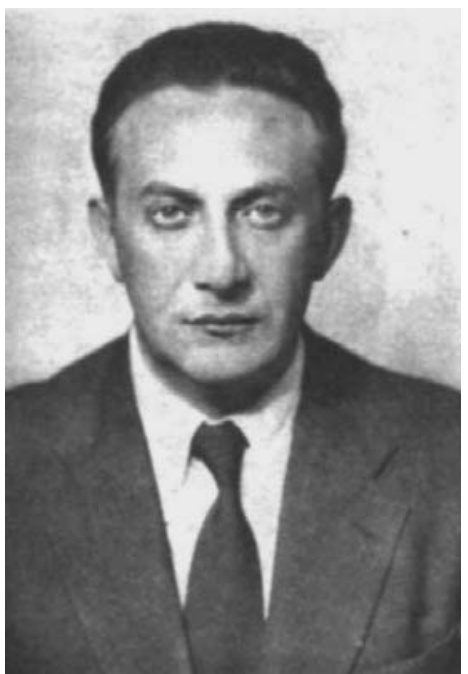

Fot. 7. Siergiej Spiegelglas 


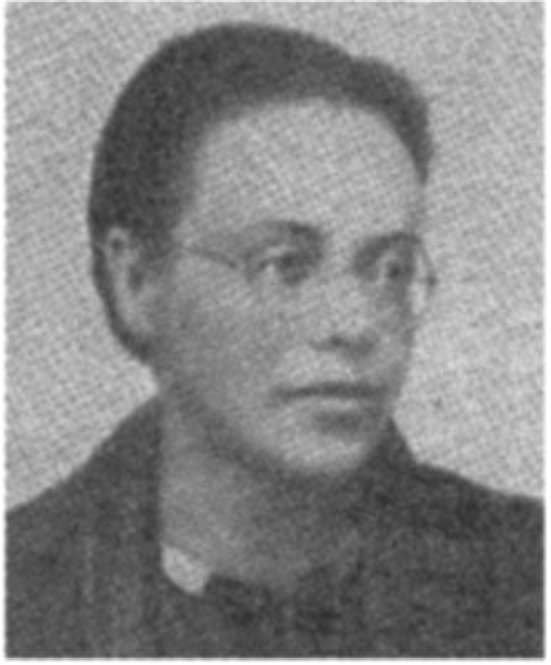

Fot. 8. Gertruda Schildbach

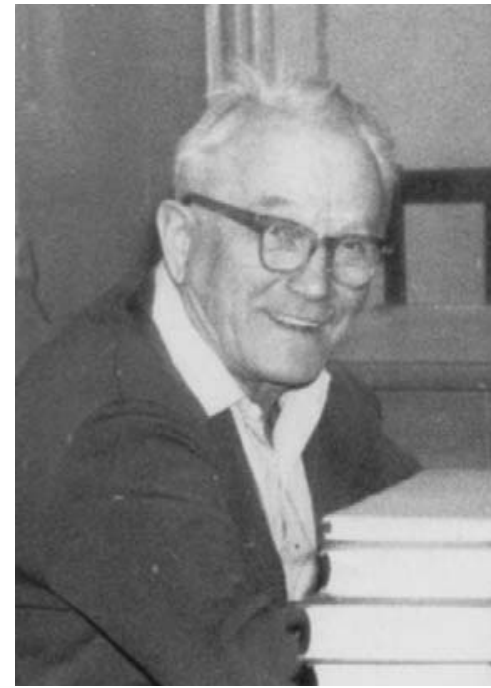

Fot. 10. Dmitrij Smirenski

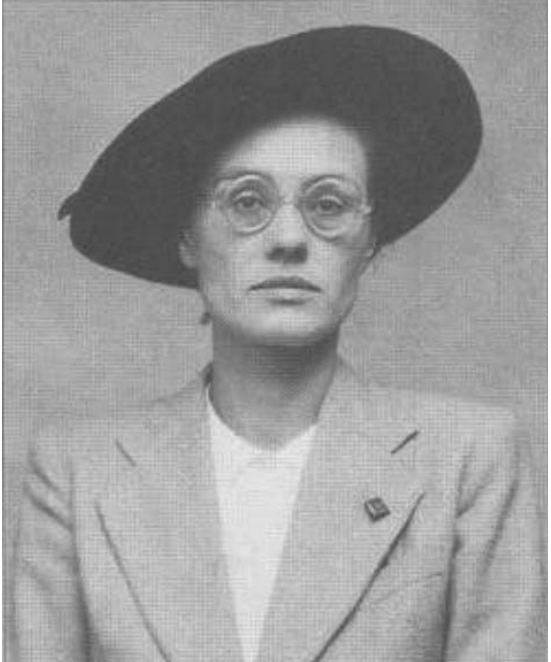

Fot. 9. Wiera Guczkowa-Traill

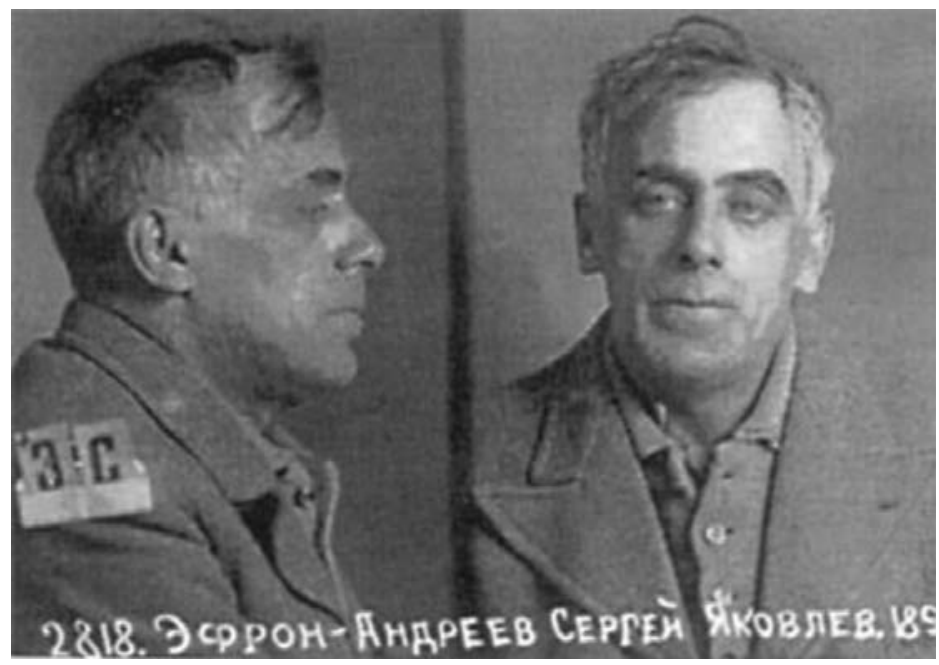

Fot. 11. Siergiej Efron po uwięzieniu przez NKWD

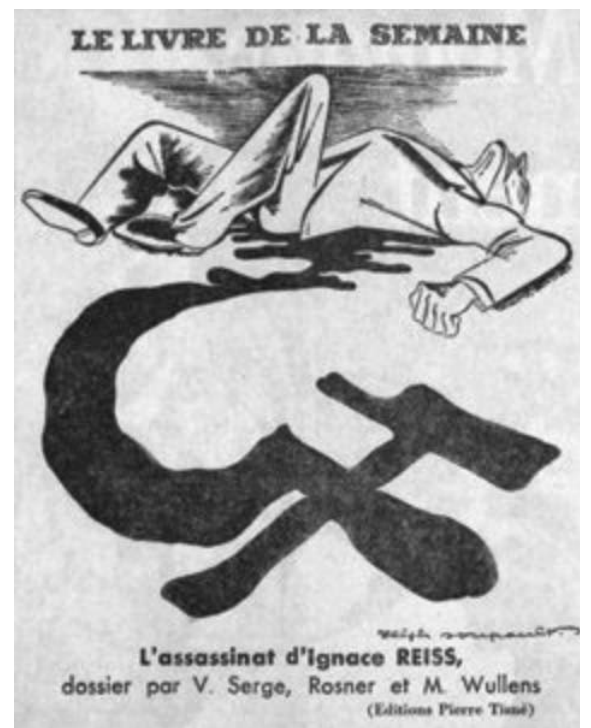

Fot. 12. Okładka książki o zabójstwie Ignacego Reissa autorstwa V. Serge’a, A. Rosnera i M. Wullensa, wydanej w Paryżu w 1939 roku 